\title{
NIF Conventional Facilities Construction Health and Safety Plan
}

Daniel W. Benjamin

May 14, 1998 


\section{DISCLAIMER}

This document was prepared as an account of work sponsored by an agency of the United States Government. Neither the United States Government nor the University of California nor any of their employees, makes any warranty, express or implied, or assumes any legal liability or responsibility for the accuracy, completeness, or usefulness of any information, apparatus, product, or process disclosed, or represents that its use would not infringe privately owned rights. Reference herein to any specific commercial product, process, or service by trade name, trademark, manufacturer, or otherwise, does not necessarily constitute or imply its endorsement, recommendation, or favoring by the United States Government or the University of California. The views and opinions of authors expressed herein do not necessarily state or reflect those of the United States Government or the University of California, and shall not be used for advertising or product endorsement purposes.

This work was performed under the auspices of the U. S. Department of Energy by the University of California, Lawrence Livermore National Laboratory under Contract No. W-7405-Eng-48.

This report has been reproduced directly from the best available copy.

Available electronically at http://www.doc.gov/bridge

Available for a processing fee to U.S. Department of Energy

And its contractors in paper from

U.S. Department of Energy

Office of Scientific and Technical Information

P.O. Box 62

Oak Ridge, TN 37831-0062

Telephone: (865) 576-8401

Facsimile: (865) 576-5728

E-mail: reports@adonis.osti.gov

Available for the sale to the public from

U.S. Department of Commerce

National Technical Information Service

5285 Port Royal Road

Springfield, VA 22161

Telephone: (800) 553-6847

Facsimile: (703) 605-6900

E-mail: orders@ntis.fedworld.gov

Online ordering: http://www.ntis.gov/ordering.htm

OR

Lawrence Livermore National Laboratory

Technical Information Department's Digital Library

http://www.llnl.gov/tid/Library.html 
NIF Conventional Facilities Construction Health and Safety Plan

NIF-0004757

NIF Conventional Facilities Construction Health and Safety Plan

Responsible Individual:

Reviewed and Accepted by:

Concurred by:

Concurred by:

Approved by:

Approved by:
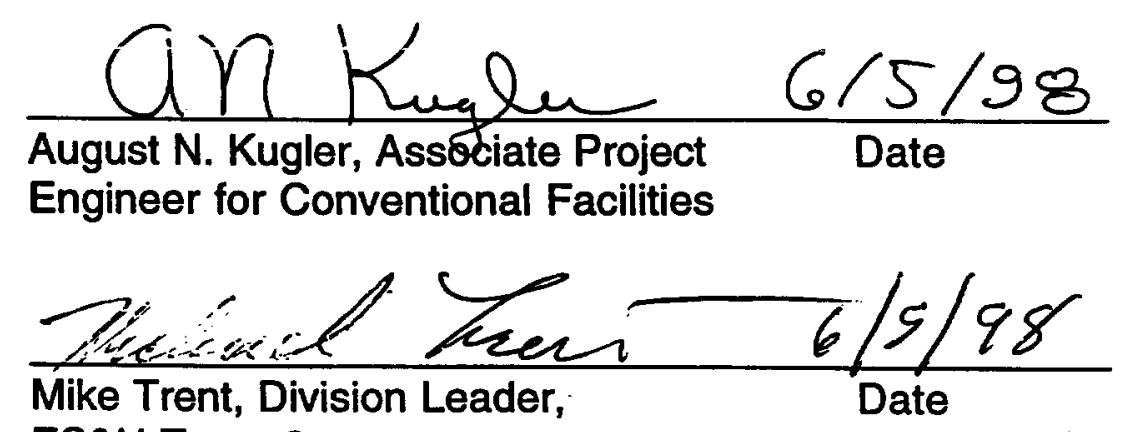
ES\&H Team 2

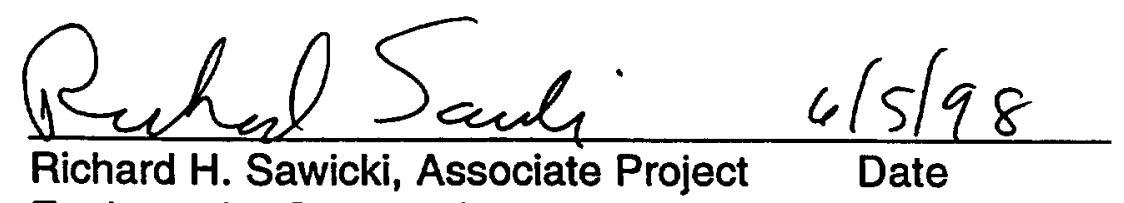

Engineer for Special Equipment

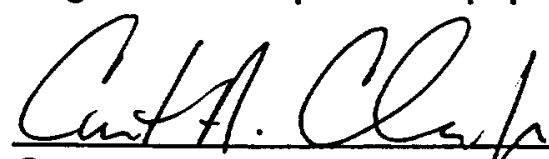

Curtis A. Cower, Associate Project

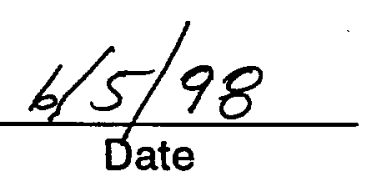

Engineer for Startup and Operations Engineering
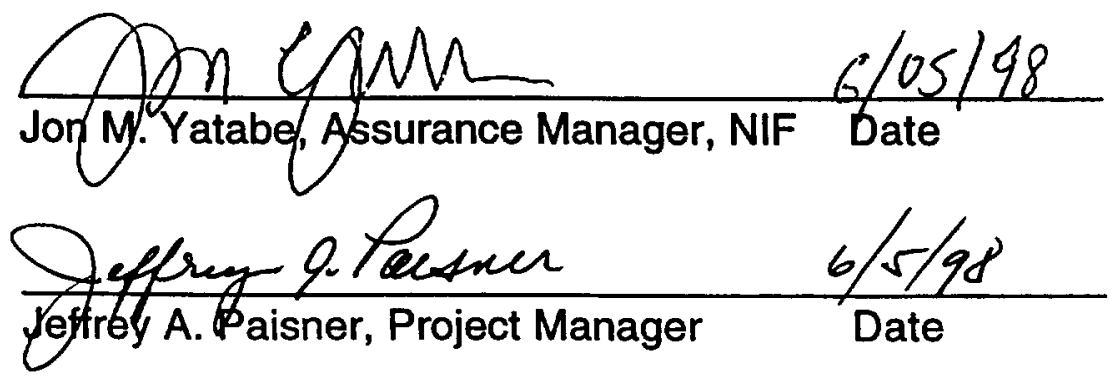

i 


\section{Table of Contents}

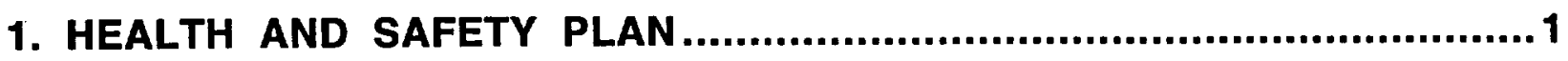

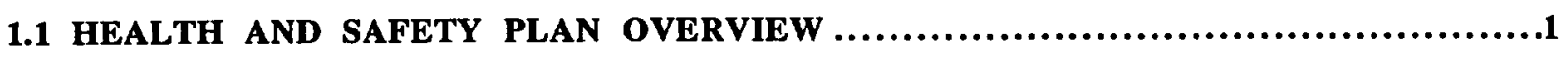

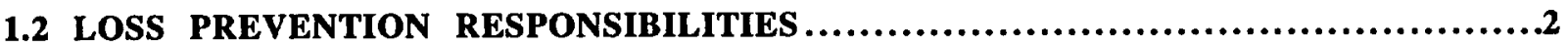

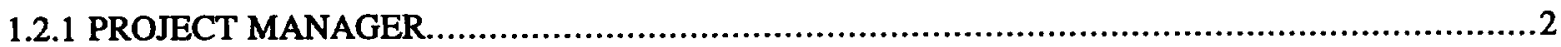

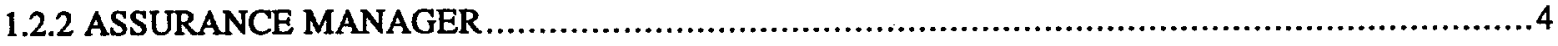

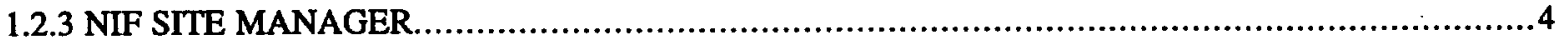

1.2.4 ASSOCLATE PROJECT ENGINEERS...........................................................................

1.2.5 CONVENTIONAL FACILITIES, START-UP/OPERATIONS ENGINEERING AND SPECIAL

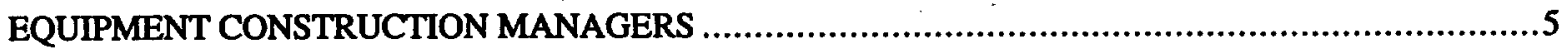

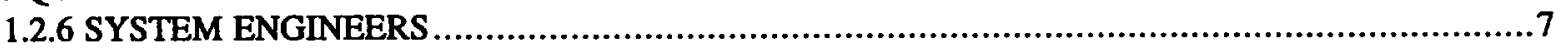

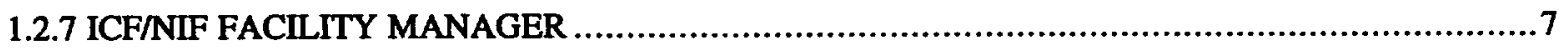

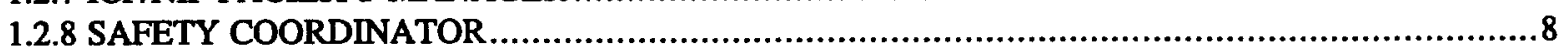

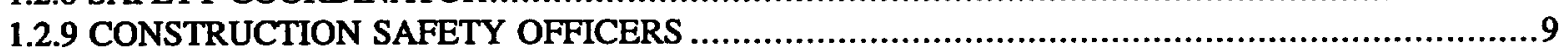

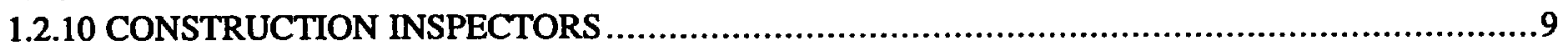

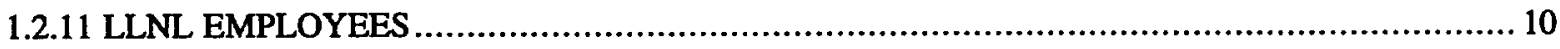

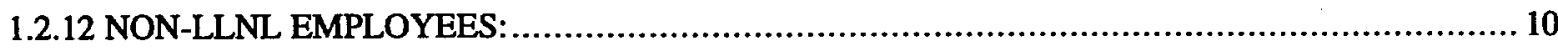

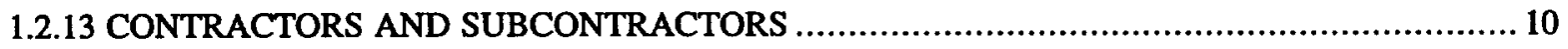

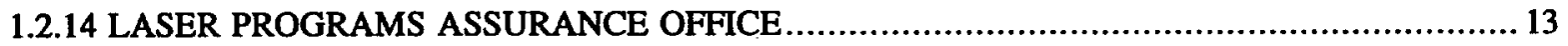

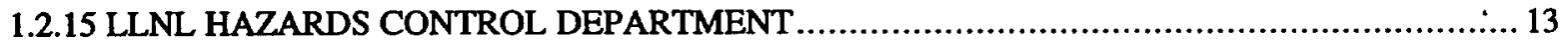

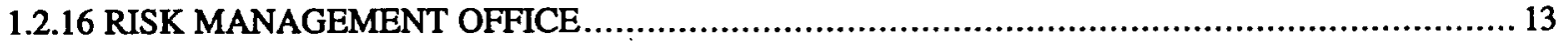

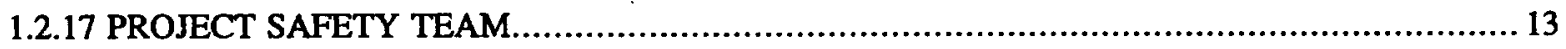

1.2 .18 LEVEL I AND LEVEL II REQUIREMENTS ....................................................... 13

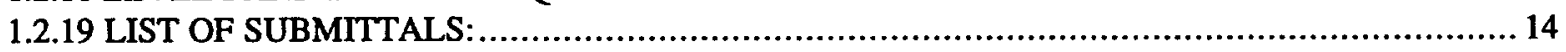

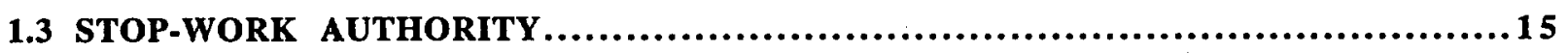

1.4 EMERGENCY RESPONSE PROCEDURES, FIRST AID AND MEDICAL CARE, EMERGENCY PREPAREDNESS/SELF HELP....................................16

1.5 ACCIDENT/INCIDENT INVESTIGATION AND REPORTING PROCEDURES.........17

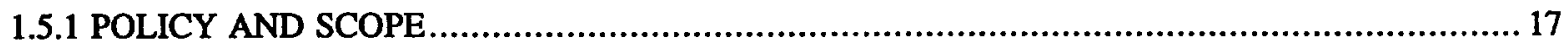

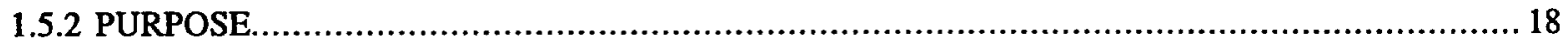

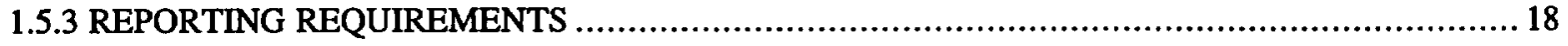

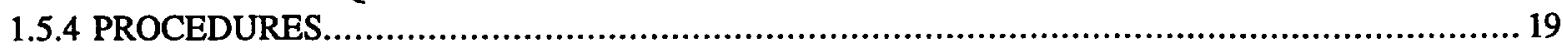

1.5.5 INJURY/DAMAGE ACCIDENTS INVOLVING OUTSIDE PERSONS OR PROPERTY ............. 20

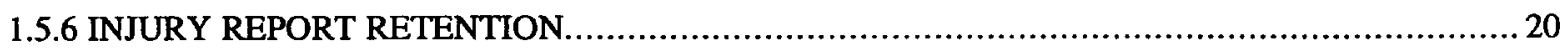

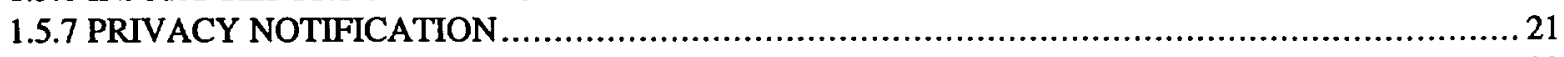

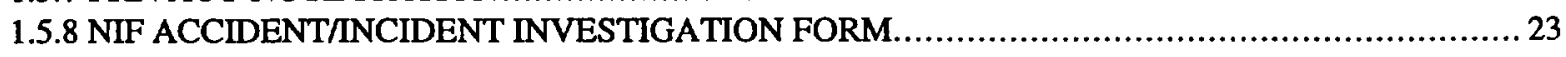

1.6 DRUG-FREE WORKPLACE PROGRAM......................................26

2. PREPHASE PLANNING_JOB hAZARD ANALYSIS .........................27

2.1 SCOPE.........................................................................27 


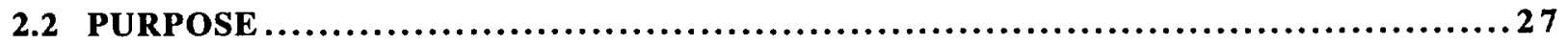

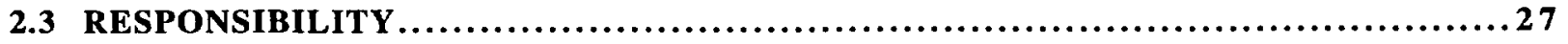

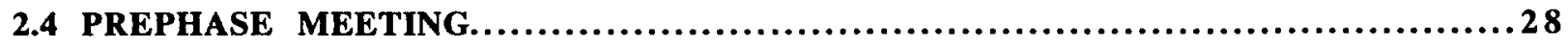

2.5 FIVE-MinUte SAFETY PLANNING MEETING $\ldots \ldots \ldots \ldots \ldots \ldots \ldots \ldots \ldots \ldots \ldots \ldots \ldots \ldots$

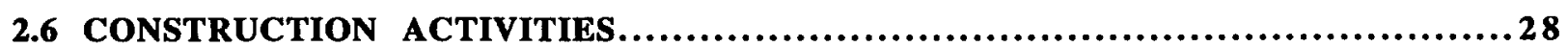

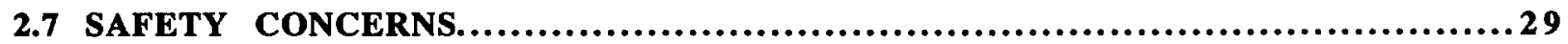

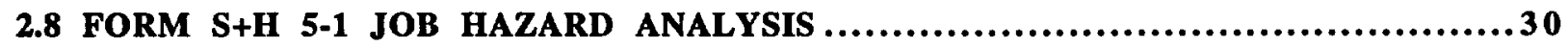

\section{HAZARD COMMUNICATION AND HAZARDOUS MATERIAL}

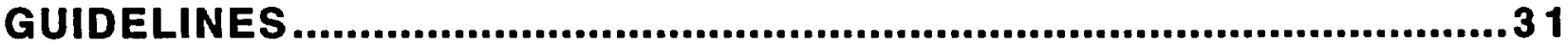

3.1 HAZARD COMMUNICATION........................................................ 31

3.2 HAZARDOUS MATERIAL AND WASTE MANAGEMENT GUIDELINES..............31

4. EMPLOYEE SAFETY AND HEALTH RULES .................................. 32

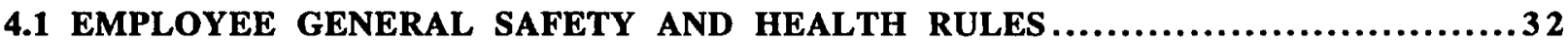

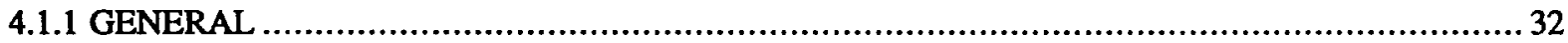

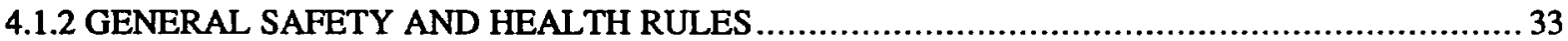

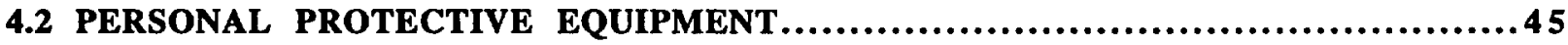

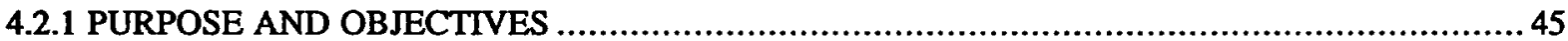

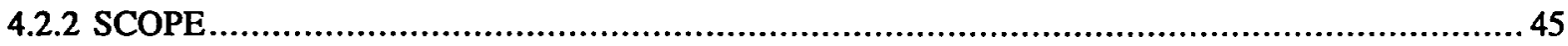

4.2.3 NIF CONSTRUCTION SAFETY PROGRAM POLICY . ........................................... 45

4.3 FORM S+H A-1 - SAFETY RULES TRAINING, ORIENTATION, AND

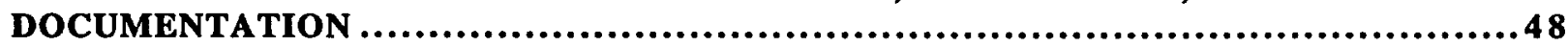

5. SAFETY TRAINING MEETING TALKS.............................................49

5.1 GUIDELINES FOR SAFETY TRAINING MEETINGS $\ldots \ldots \ldots \ldots \ldots \ldots \ldots \ldots \ldots \ldots \ldots \ldots . \ldots . \ldots \ldots$

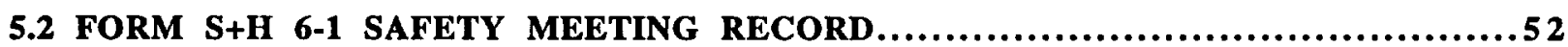




\section{Health and Safety Plan}

\subsection{HEALTH AND SAFETY PLAN OVERVIEW}

The purpose of this Plan is to outline the minimum health and safety requirements to which all participating Lawrence Livermore National Laboratory (LLNL) and non-LLNL employees (excluding National Ignition Facility [NIF] specific contractors and subcontractors covered under the construction subcontract packages (e.g., CSP-9)-see Construction Safety Program for the National Ignition Facility [CSP] Section I.B. "NIF Construction Contractors and Subcontractors" for specifics) shall adhere to for preventing job-related injuries and illnesses during Conventional Facilities construction activities at the NIF Project. For the purpose of this Plan, the term "LLNL and non-LLNL employees" includes LLNL employees, LLNL Plant Operations staff and their contractors, supplemental labor, contract labor, labor-only contractors, vendors, DOE representatives, personnel matrixed/assigned from other National Laboratories, participating guests, and others such as visitors, students, consultants etc., performing on-site work or services in support of the NIF Project. Based upon an activity level determination explained in Section 1.2.18, in this document, these organizations or individuals may be required by site management to prepare their own NIF site-specific safety plan. LLNL employees will normally not be expected to prepare a site-specific safety plan. This Plan also outlines job-specific exposures and construction site safety activities with which LLNL and non-LLNL employees shall comply.

The Project Management Team's role in achieving construction safety and health objectives includes overseeing the site safety program. This responsibility does not supersede, override, or take precedence over that of construction contractors or LLNL or non-LLNL employers who are ultimately responsible for the safety and health of their personnel and the protection of property. The key function of the Project Management Team, as it relates to construction safety and health, is to oversee contractor and LLNL and non-LLNL employee compliance with the safety and health standards required by law, to administer and enforce the conditions of the Contract pertaining to safety, and to recognize contractors who perform within outlined goals and objectives.

The Plan does not cover the full spectrum of published safety and health standards that are mandated by law, and employees should not assume that they are responsible only for those that are referenced in this Plan, nor that they are current and quoted as published. This Plan is not all-inclusive. Other elements may be added as an Appendix or may be conveyed to individual contractors or to LLNL or non-LLNL employees to whom they may expressly apply. 
It is the employee's responsibility to ensure that they are in compliance with the injury and illness prevention guidelines set forth by the LLNL Health $\mathcal{E}$ Safety Manual, this Plan, and all related safety directives required by state and federal law. In the event of a conflict between the provisions of this Plan and applicable LLNL, federal, state, or local safety and health laws, regulations, and/or standards, the more stringent shall apply.

\subsection{LOSS PREVENTION RESPONSIBILITIES}

On a project of this scope and magnitude, it is imperative that all organizations exercise positive leadership in orienting and motivating their staff, line supervisors and employees toward performing their jobs effectively and efficiently and with a high regard for safety.

This section describes the line management organization responsibilities and interfaces regarding Environment, Safety, and Health (ES\&H) at the NIF construction site. The responsibility definitions are consistent with the NIF Project Execution Plan and the NIF Site Management Plan. The NIF Project Manager responsibilities are defined for the Site Manager, Associate Project Engineers, Construction Managers (CMs), System Engineers, and, in the operating phase, the Inertial Confinement Fusion (ICF)/NIF Facility Manager. The line organization is supported by Safety officers and a Safety Coordinator. The NIF Project organization is shown in Figure 1.

\subsubsection{PROJECT MANAGER}

The Project Manager, the single-point line manager responsible for all personnel and activities of the NIF Project, has the following responsibilities relative to the construction site:

- Serves as the point of contact and interface with the Department of Energy (DOE) Field and Headquarters Office and other agencies.

- Establishes and controls the technical, cost, and schedule baselines and reports project status against the baselines to the DOE. Enforces all policies and procedures to assure that cost, schedule, and performance requirements will be achieved.

- Ensures that environmental, safety, radiation protection, quality assurance, and security programs are established and maintained to meet all applicable, federal, state, and local regulatory requirements. Establishes and implements the Construction Safety Program.

The Project Manager plans and implements the facility construction, equipment procurement, and equipment installation by working through the Conventional Facilities, Optics and Materials Technology, Special Equipment, and Startup/Operations Engineering Associate Project Engineers. 
The Project Manager also provides for the activation, operational readiness review, and ultimate operation of the NIF Facility through the Start-up and Operations Engineering Associate Project Engineer. The Project Manager is responsible from the start-up of the first laser bundle to the completion of the Operational Readiness Review, at which point the ICF Program assumes responsibility for facility operation under the ICF/NIF Facility Manager.

The Project Manager delegates responsibility to the Site Manager for controlling access to the site and for administering ES\&H rules and regulations for all personnel working at the site.

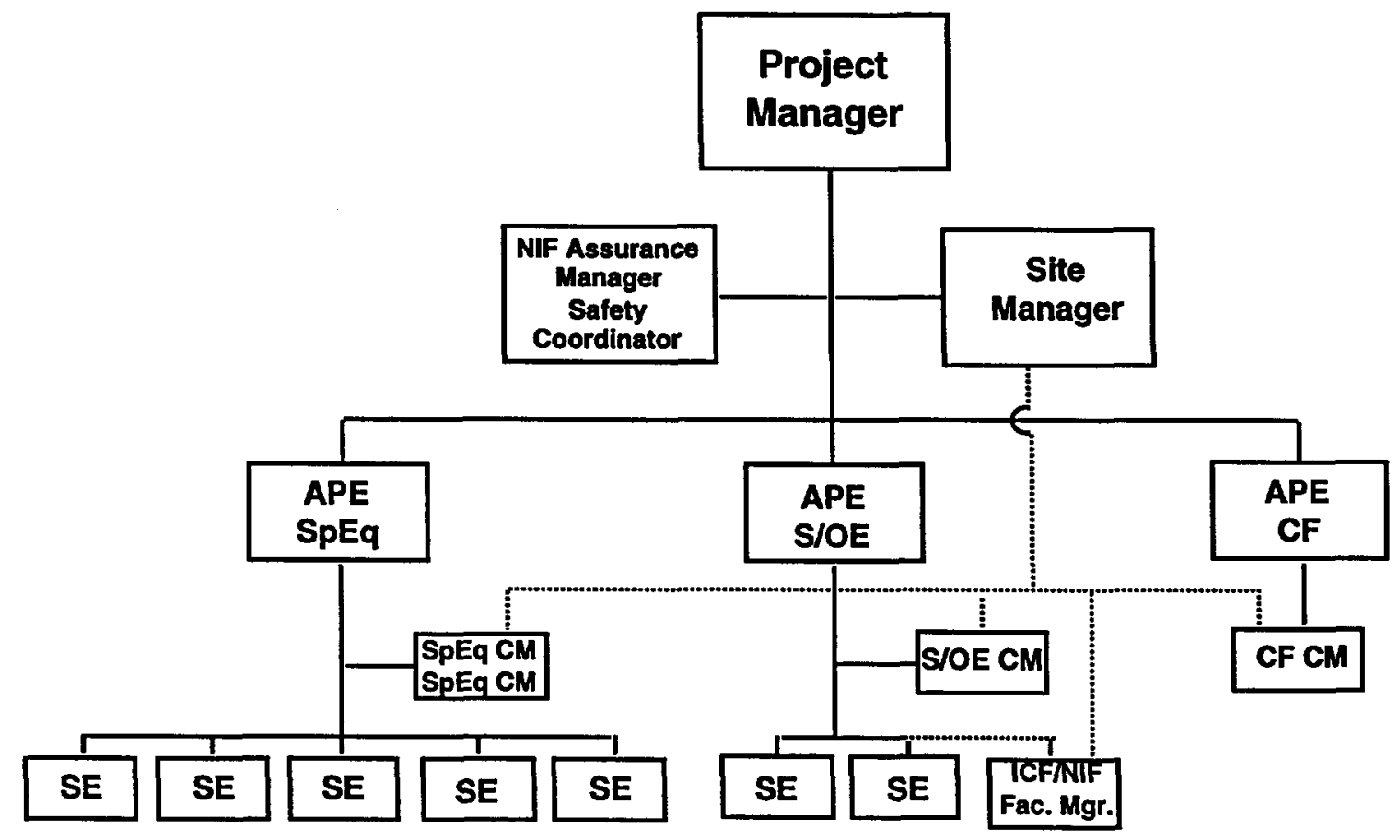

SpEq-Special Equipment

SHOE-Start-up/Operations Engineering

CF-Conventional Facilities

CM-Construction Manager

SE-System Engineer

Solid Lines-indicate direct accountability for safety, cost, schedule, and technical performance as defined herein.

Dashed LInes - Indicate coordination for Site Management and

administration as defined herein.

Figure 1. NIF Project organization. 


\subsubsection{ASSURANCE MANAGER}

The Assurance Manager reports to the Project Manager and is responsible for instituting the ES\&H policies, procedures, and infrastructure necessary to assure the safe conduct of all Project activities and for overseeing and monitoring work activities to assure compliance. The Assurance Manager is also responsible for the oversight of the quality and security aspects of the NIF Project. The detailed responsibilities are listed in Section 1.A.2 of the Construction Safety Program.

\subsubsection{NIF SITE MANAGER}

The NIF Site Manager reports to the NIF Project Manager and is responsible for establishing and maintaining safe working conditions at the site and coordinating activities among the Construction Managers. The Site Manager has the following responsibilities:

- Controls access to the site and administers the rules and regulations that must be adhered to by anyone working on the site. This includes an extensive set of safety and training requirements.

- Assigns areas of the site to Construction Managers and approves any transfer of area responsibility between CMs.

- Anticipates and resolves space, equipment availability, personnel, and schedule conflicts while minimizing Project costs and achieving the earliest performance of NIF operational objectives. Has responsibility for interface resolution between areas and systems as described in the Site Management Plan. Conducts site coordination meetings (frequency based on level of work activity).

- Coordinates and interfaces with the Conventional Facilities Construction Manager, Special Equipment Construction Managers, Start-up and Operations Engineering Construction Manager, and the ICF/NIF Facility Manager.

- Concurs on the content of the Construction Safety Program, the Startup/Operations Engineering and Special Equipment Construction Health and Safety Plan, Conventional Facilities Construction Health and Safety Plan, and all other site specific health and safety plans.

- Assumes Project lead on the direct reporting chain for site accidents and near misses.

- Concurs with the System Engineers and Construction Managers on the determination of Level 1 contractors (see Section 1.2.18).

The Site Manager does not have line responsibility over the Associate Project Engineers or their Construction Managers. However, the individual Construction Managers for the Laser Bay, Target Area, Conventional Facilities, and Start-up and Operations Engineering are accountable to the Site Manager for conducting their activities within the ES\&H rules and regulations on the site (see Section 1.2.5). For Facilities (e.g., Optics Assembly Building [OAB]) turned over for Program operation, 
the ICF/NIF Facility Manager directly interfaces with the Site Manager on facility/equipment availability, personnel, schedule coordination, and conflicts.

\subsubsection{ASSOCIATE PROJECT ENGINEERS}

The Associate Project Engineers report to the Project Manager. They are the line managers responsible for all work performed during design, assembly, installation, and start-up; for ensuring that the work is done safely within cost and schedule constraints; and for ensuring that the system is capable of meeting all performance milestones. The responsibilities of the Associate Project Engineers relative to the construction site are:

- Ensure that the activities under their direct responsibility (e.g., installation of equipment, conventional facility construction, etc.) meet all applicable ES\&H, performance category, Quality Assurance (QA), security, and other regulatory requirements. Ensure through the System Engineers/Construction Managers that applicable ES\&H requirements are placed in all procurements and that these requirements are implemented properly by the contractors and subcontractors.

- Develop the cost estimate and schedule for their area of responsibility. Ensure that the Project-approved cost and schedule baselines for their area of responsibility are met and that any variances are resolved through the Project change process.

- Ensure that their personnel and contractors meet ES\&H training and qualification requirements.

- Manage and direct their staffs, providing system design criteria, interface control diagrams, and Title I, II, and III design, acquisition, construction, installation, and/or activation of their assigned area of responsibility. Report any changes that potentially affect site activities immediately to the Site Manager. Direct the work of contractors and subcontractors through their System Engineers/Construction Managers.

- Input, review, and concur with Project near-term schedule prepared by the Start-up/Operations Engineering organization.

The Associate Project Engineers delegate to their respective Construction Manager(s) the responsibility for coordination of site construction activities, including assurance that all ES\&H and QA requirements are met.

\subsubsection{CONVENTIONAL FACILITIES, START-UP/OPERATIONS ENGINEERING AND SPECIAL EQUIPMENT CONSTRUCTION MANAGERS}

The four Construction Managers provide safety oversight of all individuals on the construction site, including LLNL employees, non-LLNL employees, construction and installation contractors, and construction subcontractors. Their responsibility is divided up by assigned NIF areas in accordance with the Site Management Plan and overall project schedule. These managers report directly to the Associate Project Engineers for Conventional Facilities, Special Equipment, and 
Start-up and Operations Engineering and are responsible to them for coordinating site construction activities to assure safe and efficient work activities. They are responsible for establishing the specific conditions under which work is performed and for integrating and coordinating all activities at the construction site according to rules and regulations for the NIF site under the aegis of the Site Manager. It is their responsibility to immediately apprise the Site Manager of any issue that potentially affects safety or schedule issues or could cause construction interference at the site. Their common safety responsibilities are:

- Ensure that the Conventional Facilities, Special Equipment, and Start-up and Operations Engineering activities are coordinated with respect to safety. When the facilities are turned over and operations begin, the Construction Managers also interface with the ICF/NIF Facility Manager.

- Verify that the LLNL employees, non-LLNL employees, construction contractors (excluding NIF specific contractors and subcontractors), and construction subcontractors are performing all work in accordance with applicable ES\&H standards and the NIF Construction Safety Program within their assigned area.

- Control access to the area assigned.

- Prepare site accident reports and provide follow-up (e.g., final report, corrective actions). Ensure that reporting goes through the proper chain of authority.

- Perform liaison with the Safety Coordinator.

- Be a member of the Project Safety Team.

- Verify that construction contractors/subcontractors have adequate Safety Plans or provide to them this Safety Plan for their scope of site activities.

- Confirm that all worker safety training and orientation requirements are met.

- Verify that environmental permits are in place (e.g., Storm Water Pollution Prevention Plan [SWPPP], etc.).

- Review the results of the safety audits for compliance, recommendations made for correction and prevention of recurrence, and follow-up measures taken to ensure compliance.

- Review records of all accidents experienced by workers in their area, look for trending causes, and take corrective action as appropriate.

The Construction Manager for Lasers and the Construction Manager for Start-up and Operations Engineering coordinate space and time for site activities of other System Engineers.

The Construction Manager for Conventional Facilities has the additional safety responsibilities to:

- Develop and implement the owner-controlled insurance program (OCIP).

- Ensure that all Conventional Facilities personnel are familiar with and comply with the OCIP. 
- Perform the duties of the System Engineer as outlined in Section F as they relate to Conventional Facilities.

\subsubsection{SYSTEM ENGINEERS}

The Systems Engineers are each responsible for a major Project activity. The System Engineers report to the Associate Project Engineers. Their common safety responsibilities are:

- Support the Contracting Officer in the bid/award process for construction contractors and subcontractors, ensuring that safety-related requirements (Level 1 requires CM and Site Manager concurrence) are adequately implemented in the bid/award packages. Direct the contractors and subcontractors working at the construction site.

- Ensure that the LLNL employees, non-LLNL employees, construction contractors, and construction subcontractors are performing all work in accordance with applicable ES\&H standards and the facilities requirements for the NIF.

- Ensure the development of Job Hazards Analyses (JHAs).

- Coordinate site work activities and interface with the appropriate Construction Manager(s).

System Engineers will verify that the following safety requirements are met for their area of responsibility:

- A safe and healthy work environment is established and maintained by adherence to the guidelines and procedures issued in the latest document of the federal, state, and site-specific requirements.

- All LLNL and non-LLNL employees and contractors/subcontractors implement and abide by the ES\&H rules and regulations set forth by all regulatory agencies, as well as those identified in the Construction Safety Program for the NIF.

- Work activities are preplanned in order to identify and control any safety and health issues that may pose a hazard to workers or others.

- JHAs are prepared for the planned activities.

- Communications with contractors/subcontractors are maintained.

- Construction Safety Program general requirements are applied to visitors.

- Specific job safety training is completed.

- Safety audits are performed and deficiencies corrected.

- Investigation of all injuries, accidents, and incidents are conducted.

- Safety inspections with LLNL and non-LLNL employees and their contractors/subcontractors are reviewed.

\subsubsection{ICF/NIF FACILITY MANAGER}

The ICF/NIF Facility Manager has facility responsibility for the NIF-related ICF Facilities including the $\mathrm{OAB}$ and Laser and Target Area Building areas as they are turned over for operations. The ICF/NIF Facility Manager reports to the ICF/NIF 
Program but is responsible for coordinating these activities through the Site Manager (see Figure 1) to ensure that NIF ES\&H requirements and schedules are maintained. The ICF/NIF Facility Manager has the following responsibilities:

- Interfaces with the Site Manager on priorities vis-à-vis installation, potential interference, and start-up to ensure that the Project completion schedule is not impacted by program facility operations.

- Interfaces with the CM for Start-up/Operations Engineering on safety issues and serves as the interface between Start-up and Operations Engineering.

- Directs the day-to-day operation and maintenance of the NIF related Program facilities. Interfaces with the NIF user organizations to ensure the safety of proposed tests (a panel of safety experts supports this activity).

- Oversees the environmental compliance of the operating facilities with permits (e.g., National Emissions Standards for Hazardous Air Pollutants, SWPPP) and other regulatory requirements (e.g., Environmental Protection Agency, etc.)

- Prepares and implements training plans, procedures, Facility Safety Procedures, Operational Safety Requirements, and Operational Safety Procedures.

- Verifies that applicable ES\&H and Quality Assurance requirements for the operating facilities are carried out.

- Controls security and access during test shots.

- Verifies that the radiation protection program is established and implemented.

\subsubsection{SAFETY COORDINATOR}

The Safety Coordinator represents the ES\&H support for line management and reports to the NIF Assurance Office. The Safety Coordinator has the following responsibilities:

- Assists the Site Manager, Associate Project Engineers, and the CMs with the coordination of concurrent construction site work activities related to ES\&H.

- Act as interface among CMs and Safety Officers on ES\&H issues pertaining to the construction site work activities.

- Chairs the Project Safety Team Meetings.

- Performs safety audits and interfaces with DOE and other external audits.

- Prepares and revises as necessary a safety and health plan applicable to the overall NIF Project, e.g., the Construction Safety Program for the National Ignition Facility.

- Coordinates the review of Health and Safety Plans, e.g., Conventional Facilities Construction Health and Safety Plan, contractor/subcontractor safety plans, JHAs, and Lessons Learned.

- Verifies that the LLNL safety policy is being implemented. 


\subsubsection{CONSTRUCTION SAFETY OFFICERS}

Construction Safety Officers represent the ES\&H support for line management, are assigned to the $\mathrm{CMs}$, are responsible for overseeing within their Element the safety of LLNL employees, non-LLNL employees, construction contractors, and construction subcontractors during the NIF construction project. They have the following responsibilities:

- Act as point contact and interface with the Hazards Control ES\&H Team 2 on construction site-related ES\&H issues pertaining to their assigned NIF Element.

- Review the ES\&H aspects of the construction site work in their assigned Element with the construction site work in other Elements.

- Assist with resolving ES\&H issues.

- Review work practices of LLNL employees, non-LLNL employees, construction contractors, and construction subcontractors (associated with the assigned Element) to assure all work is being performed in accordance with applicable ES\&H standards.

- Perform formal safety compliance audits and inspections and document findings.

- Review the results of safety compliance audits and inspections, provide recommendations for correction (and prevention of recurrence) of noncompliance findings; and identify necessary follow-up measures to ensure future compliance.

- Assist the Site Manager, Associate Project Engineers, System Engineers, and CMs with investigations of injuries, accidents, and incidents.

- Assist with preparation (and updates) of the Safety Plan for their assigned NIF Element.

- Support review of Safety Plans of primary contractors/subcontractors to ensure such plans are consistent with LLNL policies and the NIF Construction Safety Program requirements.

- Request and coordinate support of the Hazards Control ES\&H Team to resolve specific safety issues.

- Be a member of the Project Safety Team.

- Review and disseminate Lessons Learned.

- Review and coordinate development of JHAs.

\subsubsection{CONSTRUCTION INSPECTORS}

The Construction Inspectors (may also be known by other similar titles) are the primary field contact to LLNL and non-LLNL employees and their contractors/subcontractors for a specific NIF element including Conventional Facilities. He/she will monitor his/her safety program on a daily basis and notify the Conventional Facilities Construction Manager and/or the Construction Safety Officer when improper working conditions are identified. 


\subsubsection{LLNL EMPLOYEES}

LLNL employees are University of California employees whose payroll and benefits are administered by LLNL. Their responsibilities include knowing and understanding the ES\&H requirements of their assignments and the potential hazards in the work area; performing work assignments in full compliance with applicable ES\&H requirements in Laboratory manuals, guidelines, and established in the safety plan of the NIF Element for which they are assigned; participating in all training, personnel, and health monitoring programs required by LLNL; and immediately correcting or informing the responsible supervisor of any ES\&Hrelated problems.

\subsubsection{NON-LLNL EMPLOYEES:}

Non-LLNL employees, as defined in the CSP, Section I.A.14 and Section 1.1 of this Plan, are responsible for following all safety and health requirements of their own parent organization and all requirements of this Plan. They must report all work-related injuries and illnesses to NIF Project Management, and they must use the same protective equipment and safety controls required for any employee working in the area. Refer to Section I.A.14 of the CSP for a complete listing of responsibilities.

\subsubsection{CONTRACTORS AND SUBCONTRACTORS}

Contractors and subcontractors, e.g., contractors to Plant Operations performing on-site work or services under the definition of non-LLNL employees in this Plan, are required to maintain the following basic environmental, safety, and health procedures:

- As a condition of their contract or subcontract, assume responsibility for the safety and health of their employees, agents, subcontractors and their employees, and other persons representing them on the Work Site.

- (Level II requirement) Assign an on-site "Competent" Safety Representative for each contract or subcontract whose duties include the protection of persons and property and the administration of the safety plan. The name of this individual shall be provided to the NIF Project Management upon award of the contract.

A "competent" safety representative is capable of identifying existing and predictable hazards in the surroundings or working conditions that are unsanitary, hazardous, or dangerous to employees and has the authority to take prompt corrective measures to eliminate them. A "competent" safety representative is also an individual who has received the proper Occupational Safety and Health Administration (OSHA) training necessary to understand and properly address unsafe conditions surrounding construction site exposures. 
- (Level II requirement) Delegate a "competent" safety representative to attend and complete the 10-hour OSHA safety training course. This training will be provided upon the contractor's request at no cost to the NIF.

- As required through California (CAL)/OSHA's Injury and Illness Prevention Program (IIPP), investigate accidents/incidents, determine causes, and develop/implement corrective actions to prevent reoccurrences. All contractors/subcontractors are responsible for immediately notifying NIF Project Management regarding any near misses or accidents. Completed accident investigation reports, findings, and corrective measures should be faxed to NIF Project Management.

- Comply with CAL/OSHA's Title 8, Article \#3, General Industry Safety Orders 1505 , IIPP, and all applicable laws, regulations, ordinances, conditions of contract/subcontract, and rules or orders of any public authority having jurisdiction relating to safety of persons or property.

- Ensure that all of their employees, subcontractors, and their subcontractors' employees are briefed on applicable LLNL ES\&H policies/procedures and NIF's Facilities requirements. All of their employees, subcontractors, and their subcontractors' employees are required to attend a 30-minute safety orientation session that will be provided by the Construction Manager for Conventional Facilities in the on-site NIF Safety/Labor Relations trailer prior to performing any work on the site. Contractors/subcontractors shall, in accordance with law, adopt procedures providing that any employee who carelessly or callously disregards these rules or other applicable safety and health regulations shall be subject to disciplinary action up to and including discharge.

- Submit OSHA 200 logs and total man-hours worked on a monthly basis to the NIF Project Management.

- Have their safety representative participate in the safety walk-through meetings.

- Ensure (with respect to their employees) that:

- Prior to the performance of any work, each employee involved in the NIF Project knows and understands each of the ES\&H and security rules that apply to the job site in which he/she is working.

- Each employee assumes responsibility for his/her protection.

- Personal protective equipment (inclusive of mandatory American National Standards Institute [ANSI]-approved hard hats, appropriate Noise Reduction Rating [NRR] hearing protection, appropriate footwear, and ANSI-approved safety glasses) shall be used where required and maintained in proper condition.

- $100 \%$ personal eye wear protection is required in all construction work areas, and it shall be worn at all times by employees of both the contractor and subcontractors, regardless of tier. Eyewear shall conform to applicable ANSI Z87.1. 
- Employees on walking and or working surfaces with unprotected sides or edges six feet (6) or higher above a lower level shall be protected from falling by the use of guardrails or personal fall arrest systems. This shall include but is not limited to employees on the face of formwork, reinforcing steel or structural steel during and after erection, exterior and interior masonry work, roofing work, window installation, electrical work, mechanical work, and all other trades that require work in areas where the height exceeds six (6) feet above the ground or work surface.

- Employees do not engage in practical jokes and/or horseplay.

- Employees do not undertake work that they are not properly qualified or equipped to do. In this regard, each employee shall be required to attend Safety Training Meetings weekly and sign an attendance sheet.

- Employees are aware that use of intoxicating or unlawful substances during working hours is forbidden, and any violation will be sufficient cause for dismissal and possible arrest. Employees reporting for work while under the influence of intoxicating or unlawful substances will not be allowed to assume their duties nor will they be allowed to return to the construction site.

- Employees are informed of proper storage requirements for hazardous materials (flammable, combustible, toxic, etc.) and hazardous wastes in accordance with the NIF Construction SWPPP.

- Employees are provided with information and training on the Hazard Communication Standard in the employer's Hazard Communication Program and on Material Safety Data Sheets (MSDSs). In addition, each contractor/subcontractor is responsible for providing copies of MSDSs and information on personnel protection measures to all affected employees. Copies of MSDSs shall also be provided to the NIF Project Management.

- Contractors/subcontractors are responsible for daily cleaning of work areas and debris removal.

- Employee must always know where they are in relation to the work in progress and avoid hazardous situations around equipment or construction in progress. Employees must advise supervisory personnel of their work location. They shall not work alone in an isolated area until arrangements have been made for periodic contact with another employee or supervisor.

- Employees must complete a preshift, self-inspection checklist for safety hazards and discrepancies to be corrected before work begins.

- One week prior to construction activities involving either construction operations or other hazardous operations, a JHA shall be prepared and submitted to NIF Project Management for review and approval.

- At the beginning of each shift there will be at least a 5-minute safety meeting to discuss the day's overall activities with each crew and the specific activities they are to perform. 
- Provide modified duty when available and case management procedures for all injured employees.

\subsubsection{LASER PROGRAMS ASSURANCE OFFICE}

The Lasers Programs Assurance Office provides a central programmatic interface and assurance function for ES\&H activities. This office is responsible for preparing program-wide ES\&H plans, monitoring and inspecting program activities, tracking ES\&H deficiencies, and reviewing occurrence reports. Refer to Section I.C of the CSP for a complete listing of responsibilities.

\subsubsection{LLNL HAZARDS CONTROL DEPARTMENT}

The LLNL Hazards Control Department is responsible for assisting with reducing the risk of workplace hazards by providing expertise, guidance, and services.

ES\&H Team 2 provides technical and oversight support to the NIF Project Office. The Emergency Management Division manages the LLNL Fire Department and the LLNL On-site Emergency Preparedness Program. Refer to Section I.D of the CSP for a complete listing of responsibilities.

\subsubsection{RISK MANAGEMENT OFFICE}

The Risk Management Office manages the Laboratory's Self-Insurance Program, which includes the Workers' Compensation and general liability programs. Refer to Section I.E of the CSP for a complete listing of responsibilities.

\subsubsection{PROJECT SAFETY TEAM}

The Project Safety Team shall consist of individuals from LLNL support organizations, the NIF Project Office, the Conventional Facilities element, and DOE. The Project Safety Team shall review, coordinate, and communicate construction safety issues. Refer to Section I.G of the CSP for a complete listing of responsibilities.

\subsubsection{LEVEL I AND LEVEL II REQUIREMENTS}

Non-LLNL employees including contractors, subcontractors, vendors, and suppliers who have activity inside the NIF site will have the activity categorized for safety requirements. As a guideline, the categorization will be based on the size of contractor, duration of operation/activity, and the complexity of the operation/activity/surroundings. Requirements will be separated into two divisions, Level I and Level II (see Table 1). The determination will be made by the Construction Safety Officer assigned to Conventional Facilities prior to the Request for Proposal (RFP). The NIF Site Manager and appropriate CM will review and concur with Level I designations. 
- Level I: Activity involving fewer than 10 employees on site, noncomplex/minor-hazard activity, short duration-less than 10 days on site.*

- Level II: Any contractor operation of significantly complex/hazardous activity, or greater than 10 employees on site, or long (continuous) durationmore than 10 days on site.

- Noncomplex/minor hazard: An activity that if not properly managed would not reasonably be expected to result in bodily injury, environmental impact, property damage, or legal liability.

- Significantly complex/hazardous: An activity that is significantly complex or significantly hazardous so that if it were not properly managed, there is a reasonable probability of death, severe bodily injury, severe adverse environmental impact, significant property damage, or substantial legal liability.

* Note: For those cases in which the risk to a Level I contractor is increased due to conditions in an area, the $\mathrm{CM}$ in charge of that area will require reevaluation and modification of the $\mathrm{JHA}$, as appropriate.

Table 1. Activity Level Requirements.

\begin{tabular}{|l|l|l|}
\hline \multicolumn{1}{|c|}{ Requirement } & \multicolumn{1}{|c|}{ Level I } & \\
\hline Competent Safety Rep. & $\#$ & $\mathrm{x}$ \\
\hline 10-Hour OSHA Class & $\#$ & $\mathrm{x}$ \\
\hline Site-Specific Safety Plan & + & $\mathrm{x}$ \\
\hline Job Hazard Analysis & $\mathrm{x}$ & $\mathrm{x}$ \\
\hline $\begin{array}{l}\text { Injury and Illness Prevention } \\
\text { Program }\end{array}$ & $\mathrm{x}$ & $\mathrm{x}$ \\
\hline $\begin{array}{l}\text { Compliance with NIF } \\
\text { Conventional Facilities } \\
\text { Construction Health and Safety } \\
\text { Plan }\end{array}$ & $\mathrm{x}$ & $\mathrm{x}$ \\
\hline
\end{tabular}

$x$ Required.

\# Will be provided by Conventional Facilities, contractor to provide designated safety representative.

\# 10-hour OSHA course for competent safety representative/supervision recommended but not required.

+ Site-specific safety plan not required.

\subsubsection{LIST OF SUBMITTALS:}

As they apply to LLNL and non-LLNL employees and their contractors/subcontractors during NIF Conventional Facilities construction activities, the following documents shall be submitted to the Conventional Facilities Construction Manager:

1. (Level II requirement) A site-specific safety plan. The plan must be reviewed and accepted by NIF Project Management prior to starting on-site work. Note: A specific safety plan will normally not be required if the contractor or 
subcontractor is specifically addressed in the safety plan as the primary contractor or primary subcontractor.

2. (Level II requirement) The name and qualifications of an on-site safety person reviewed and accepted by NIF Project Management prior to starting on-site work.

3. Current copies of weekly tool box safety meetings, when requested.

4. JHAs reviewed and accepted by the Conventional Facilities Construction Manager prior to on-site work.

5. Weekly project safety inspection and deficiency reports with solutions and corrections included.

6. Current inventory of hazardous substances on site, accompanied by MSDSs.

7. New employee orientation log (currently maintained by the Field Construction Manager for Conventional Facilities).

8. Current copy of OSHA $200 \log$ for the project.

9. Completed accident, injury, and incident reports within 24 hours of occurrence.

10. A summary of all accidents and injuries including first aid to be submitted weekly.

\subsection{STOP-WORK AUTHORITY}

Any individual working on the NIF Project who witnesses or believes a work site hazard posses an imminent danger to others has the obligation to request that a stop-work order be put into effect immediately. An "imminent danger" is any condition or practice that could reasonably be expected to cause death or serious physical harm immediately or before the danger can be eliminated by normal means.

If an imminent danger condition is observed and known to exist, the activity shall be stopped immediately, a stop-work order shall be issued, and an "UNSAFE FOR USE" notice will be posted at the site or secured to any equipment involved. The contractor's or organization's Safety Representative will be notified. The NIF Safety Coordinator and the Division Leader for ES\&H Team 2 shall also be notified immediately by the Conventional Facilities Construction Manager or on-site safety personnel when a stop-work order is issued. 
A stop-work order is normally issued by the Conventional Facilities Construction Manager, the Construction Safety Officer, or the Construction Inspector. If these people are absent, Hazards Control personnel are authorized to directly contact the personnel involved and stop the operation.

The stop-work procedure at the Laboratory applies to all NIF construction activities. The stop-work procedure will be used only where imminent danger situations exist. A stop-work order affects only those areas of the NIF construction project immediately involved in the hazardous situation. Stop-work orders may also be issued when, in the opinion of the Conventional Facilities Construction Manager, a work area is not being maintained according to the requirements of the CSP, this Plan, or the contractor's/subcontractor's Health \& Safety Plan.

Stop-work orders will be in effect until the problem(s) is resolved and the work area(s) is brought to satisfactory conformance with health and safety requirements. After a stop-work order has been issued, a resumption of work requires the concurrence of both the NIF Assurance Manager or Safety Coordinator and the Division Leader for ES\&H Team 2.

\subsection{EMERGENCY RESPONSE PROCEDURES, FIRST AID AND MEDICAL CARE, EMERGENCY PREPAREDNESS/SELF HELP}

During normal working hours (8:00 A.M. to 4:45 P.M.), all first aid and medical treatment cases will be referred to LLNL's Health Services Department, Building 663, unless specified otherwise by an employee's contract.

Outside of normal working hours (before 8:00 A.M. or after 4:45 P.M. and on week-ends), all nonemergency first aid and medical treatment cases will be referred to either Valley Care Medical Center, Eden Medical Center's Trauma Clinic, or to the nearest medical provider of choice.

All calls for emergency assistance, whether they be for medical aid or for fire fighting equipment, etc., will be dispatched by telephone through the EmergencyDispatch-Center, 911. Lab Paramedics will respond immediately to all emergencies when they are alerted through the 911 system.

\section{EMERGENCY DISPATCH 911 (Lab telephone)}

447-6880 (cell phone or other phone not connected to the LLNL exchange)

This telephone number puts you in contact with a person who can dispatch any required emergency response personnel or equipment, such as fire fighting vehicles and an air evacuation helicopter. 
Note: Non-LLNL employees will be treated in accordance with the provisions and agreements contained in their employer's individual contract with the University/LLNL.

Persons with minor injuries may be transported to local medical facilities by supervisors, coworkers, or by themselves, as appropriate.

\section{Emergency Preparedness/Self-Help}

The NIF Project realizes that during a major emergency, such as an earthquake, external help may not be immediately available. Therefore, the philosophy of emergency preparedness at the NIF relies upon the resources of individual organizations on site to protect the welfare of workers. This program is known as the "Self-Help Program." The Laser Programs have prepared an emergency response plan that includes the NIF Project entitled, "Emergency Preparedness and Response Plan for Laser Programs."

The NIF Project site and the Target Chamber construction site are included in Self-Help Zone 6. The principle assembly point for the NIF Project site is Assembly Point 6, which is located at the NE corner of Trailer 6875 (Sverdrup trailer). Other NIF Project site assembly points may be established at a later date. The Target Chamber construction site will use Assembly Point 4, which is located on the lawn area between B482 and B481. A senior person familiar with the NIF Project will be appointed as the Assembly Point Leader for Assembly Point 6.

The purpose of an assembly point is to provide a designated location where employees can assemble to be accounted for, receive instructions, and be kept informed. Emergency supplies and response instructions are stockpiled in special boxes located at the assembly points. Sweep Teams will be formed at each assembly point for the purpose of reentering facilities, if considered safe, and searching for injured personnel and hazardous situations. First Aid Teams will also be formed.

\subsection{ACCIDENT/INCIDENT INVESTIGATION AND REPORTING PROCEDURES}

\subsubsection{POLICY AND SCOPE}

It is the policy of the NIF Project to investigate all accidents/incidents related to the construction program that result in personnel injury or illness or damage to buildings or equipment, resulting from an accident or natural phenomena. As a valuable management tool, "near misses" may also be investigated for the prevention of accidents and detecting trends. "Near miss" accidents/incidents are events or a series of events that could have resulted in serious injury or illness or property damage, but did not due to circumstances or changes in events. It is the obligation of all LLNL or non-LLNL employees to investigate all occurrences, provide all information outlined below, and submit the information to Construction Management. LLNL employees and non-LLNL employees shall 
cooperate fully with the investigation of occurrences by LLNL, the University of California, or the DOE.

\subsubsection{PURPOSE}

The purpose of investigating job related accidents and illnesses is:

1. To determine cause for the purpose of preventing recurrence, and in some instances, to determine whether gross negligence was involved.

2. To comply with applicable federal, state, and local codes and regulations relating to loss reporting.

3. To provide documentation of occupational injuries and illnesses and to assist in Workers' Compensation claims management.

4. To verify data accuracy prior to external release of information.

5. To comply with LLNL Incident Analysis and Lessons Learned requirements.

\subsubsection{REPORTING REQUIREMENTS}

All LLNL and non-LLNL employees who are injured on the NIF construction site, however minor, or suspect they have developed an occupational illness shall immediately notify their on-site supervisor or NIF Project contact. In turn, the onsite supervisor or NIF Project contact will immediately notify the Conventional Facilities Construction Manager, Construction Safety Officer, or NIF Safety Coordinator who shall immediately evaluate the seriousness of the injury for additional internal notification and internal reporting.

"Near misses" are to be reported by LLNL and non-LLNL employees to the Conventional Facilities Construction Manager or appropriate Construction Manager (responsible authority). The responsible authority shall determine if an incident is worthy of being tracked/trended as a "near miss." The responsible authority can request that the "near miss" be reviewed by the NIF Project Safety Team for Lessons Learned and for the determination of its root cause. Refer to CSP, Section III.E.3, for examples of "near miss" incidents that should be reported.

LLNL employees and non-LLNL employees shall, in addition, report all injuries and occupational illnesses in accordance with existing LLNL procedures and their contractual requirements.

All incidents that result in damage to buildings, materials, or equipment; reportable releases to the environment of hazardous materials; violation of environmental permit conditions; Safeguard and Security violations; or transportation accidents must be reported to the NIF Construction Management immediately. The NIF Construction Management will immediately notify the 
appropriate LLNL organization and the NIF Safety Coordinator or Assurance Manager, who will in turn notify the Laser Programs Assurance Office contact.

Depending on the severity of the incident, the DOE Occurrence notification requirements with which the University/LLNL are contractually obligated to comply may be triggered. DOE must be notified of an incident, which LLNL has determined as reportable to them, within two hours of the occurrence of the incident. Refer to Section III.E.5 of the CSP for additional guidance.

\subsubsection{PROCEDURES}

1. All injuries, property damage, fire, incidents and accidents to LLNL and nonLLNL employees will normally be investigated by the supervisor, Construction Safety Officer, and ES\&H Team 2 member. The appropriate forms must be forwarded immediately to the appropriate safety representative and Conventional Facilities Construction Manager for review.

2. Investigation results will be reported in writing on the Project accident investigation report form. When essential information is lacking, the report will be returned for immediate completion.

3. In the event an injury is or has the possibility of being a fatality, or there is serious or fatal injury to a non-employee, or there are multiple serious injuries or extensive damage to any property, IMMEDIATE notification will be made to Construction Management and to both the insurance broker and carrier loss prevention representative.

4. A serious injury or illness is one that requires employee hospitalization for more than 24 hours for other than medical observation or one in which a part of the body is lost or permanent disfigurement occurs. The scene of any major accident must be secured until documentary, photographic, and physical evidence can be preserved. No material, machinery, or equipment should be moved until approval is given by NIF Project Management, or their representative, unless the condition or physical position poses an additional hazard.

5. All official notifications to the family of an injured employee must be in accordance with applicable LLNL Health \& Safety Manual policy.

6. LLNL employees are not to discuss with the media any facts, hearsay, or assumptions regarding accident/incidents occurring during the construction of the NIF Project. ALL releases to the news media regarding an accident must either be made or approved by the appropriate LLNL public relations representative. 


\subsubsection{INJURY/DAMAGE ACCIDENTS INVOLVING OUTSIDE PERSONS OR PROPERTY}

1. Accident reports involving any outside parties or property will include, at a minimum, the items listed in the paragraph below. In the event of a fatality, a serious injury, or a major damage accident involving outside (nonemployee) persons, the incident must be reported IMMEDIATELY to the Contractors' Safety Representative and to the CM.

2. Investigation Checklist of Minimum Required Information When an Accident Involves Outside Persons or Property:

- Date and time of incident.

- Exact location and address of incident.

- Photos of accident site.

- Full names of all parties involved in the accident, including witnesses.

- Complete addresses, telephone numbers.

- Injured person's occupation, age, and employer.

- Description of what injured person was doing when hurt.

- The nature and extent of the injury.

- Where the injured was taken for treatment. Transportation used.

- Description of property damaged, identification numbers, etc.

- Owner of property damaged and address of owner.

- Year, make, model, serial number, license number of vehicle.

- Names of other party's insurance company(s).

- Witnesses' statements or accounts of accident.

- Company personnel involved in incident-names, addresses, occupations, how involved.

- Details of incident fully described to answer the basic how, when, why questions. Name and identification of person completing the report.

- Signature of the investigator.

\subsubsection{INJURY REPORT RETENTION}

All reports pertaining to injury or illness of LLNL and non-LLNL employees shall be preserved and not destroyed without approval from the Safety Representative, NIF Safety Coordinator, NIF Project Management, and Hazards Control Department. Reports will not be released to anyone without approval of the NIF Safety Coordinator and will be kept on record for five years following the date of occurrence.

Injury and illness records on LLNL employees are covered by the DOE moratorium on the destruction of epidemiological records and will be maintained in accordance with University and Laboratory policies. 


\subsubsection{PRIVACY NOTIFICATION}

Any person working on the NIF construction site who is requested to provide personal information for accident or incident investigation purposes is to be notified, in accordance with University policy, of the following: 


\section{University of California \\ Lawrence Livermore National Laboratory \\ Privacy Notification}

The Laboratory collects and maintains information about each employee for use in miscellaneous payroll and personnel matters. The following notice with respect to that information is provided as required by the California Information Practices Act of 1977:

The principal purpose for collecting and maintaining this information is for use in matters such as, but not limited to, payment of earnings, withholding of state and federal taxes, effecting authorized payroll deductions, reimbursement for travel costs, and the administration of compensation, benefits, health and safety, and general personnel programs. Laboratory and University policy and state and federal statutes authorize the collection, maintenance, and use of this information.

The furnishing of the information requested for these purposes is mandatoryfailure to provide such information will delay and may prevent the completion of payroll and personnel actions. The information furnished will be used by various Laboratory and University departments for the above-described purposes and will be transmitted to federal and state governments as required by law.

Individuals have the right to review their own records in accordance with Laboratory and University policies. Information on these policies may be obtained from the Human Resources Manager.

The officials responsible for maintaining the above-described information are the Human Resources Manager, the Accounting Officer, the Business Services Manager, the Assistant Laboratory Director for Plant Operations, the Head of the Hazards Control Department, the Head of the Health Services Department, and the Manager of Administrative Information Services.

The above notification may be incorporated into the NIF Accident/Incident form or provided separately to the individual. 


\subsubsection{NIF ACCIDENT/INCIDENT INVESTIGATION FORM NIF CONSTRUCTION PROJECT}

\section{ACCIDENT/INCIDENT INVESTIGATION FORM}

\section{PERSONAL INFORMATION}

1. Name of Injured

Date of Hire

Date of Birth

Prime Contractor Subcontractor

Job Title SS\#

$\mathrm{hr} /$ monthly Telephone\#____-

2. Injury Date:_/_/_ Time: $\mathrm{am} / \mathrm{pm}$ Medical Care? $\mathrm{Y} / \mathrm{N}$

Treating Hospital/Clinic/Physician?

Has employee returned to work? ( $\mathrm{Y} / \mathrm{N}$, date \& time)

3. Accident Location: (Specific Site Location with reference points):

4. Type of Injury:

$$
\text { Body Part(s) Signs/Symptoms }
$$

5. Work Being Done:

$$
\text { Type of Work Equipment, tools, material in use }
$$

6. Employee trained for work? Yes_ No _ When?

Date Trainer: Name/Title

7. Employee authorized for work? Yes_ No _ If yes, 
EMPLOYEE ACCIDENT INVESTIGATION FORM (continued)

\section{ACCIDENT DESCRIPTION}

8. Accident Description: (who, when, where, how, why)

9. Result of Site Investigation: (area coned off, new procedures)

10. Result of Tool/Equipment Investigation: (defective, wrong tool)

11. Primary Accident Cause(s) \& Contributing Factors:

\section{WITNESS(ES)}

12. Name \& job position:

Relation to injured party:

Description of incidents leading to injury/illness: (one-on-one interview) 
EMPLOYEE ACCIDENT INVESTIGATION FORM (continued)

\section{RECOMMENDATIONS}

13. Job covered by:

a. Job Hazard Analysis?

Bulletin, Document, Manual, Instruct.

b. Safety rule/regulation:

Handbook, Bulletin (Citation)

14. Is the procedure/rule/regulation adequate? Yes_ No_

15. If no, recommended change(s):

16. Recommendation to prevent similar accidents:

17. Investigator(s):

Date:

19. Reviewed by:

Title

Date _/_I

III

LI_

20. Safety Committee review \& analysis: (suggestions for prevention of reoccurrence)

21. New procedures/training/controls implemented? Date _/_/_ List changes

Additional information and/or comments: 


\subsection{DRUG-FREE WORKPLACE PROGRAM}

Being under the influence of a drug or alcohol on the job may pose serious safety and health risks not only to the user but to all those who work with the user. The possession, use or sale of an illegal substance or use of alcohol in the workplace also pose unacceptable risks for safe, healthful, and efficient operations. The NIF Project Drug Free Workplace Program prohibits the possession, distribution, use, consumption or being under the influence of unauthorized alcoholic, illegal, and unauthorized substances (synthetics, designers, and other harmful substances) in order to provide a safe and healthful environment for our employees, the contractor's employees, customers, suppliers, visitors, and members of the general public.

All Laboratory employees of the University working on the NIF construction site are covered by current LLNL policy.

All non-LLNL employees working under the direction of LLNL on the NIF construction site are covered by the applicable provisions of their individual contracts with the University/Laboratory. 


\section{Prephase Planning-Job Hazard Analysis}

\subsection{SCOPE}

This procedure outlines the purpose for and method of Prephase PlanningJob Hazard Analysis (JHA) that will be required for each construction operation involving operations and/or work. A JHA form shall be prepared one week prior to any operations and/or construction activities performed by LLNL or non-LLNL employees or their contractors/subcontractors. ES\&H Team 2 and Construction Management review must be obtained prior to any on-site work activities. An Operational Safety Procedure (OSP) may also be required for some activities. Consult with ES\&H Team 2 regarding the necessity of preparing an OSP.

\subsection{PURPOSE}

The purpose of accident prevention preplanning is to prevent unnecessary hazards that are likely to occur during construction and to make sure each worker performing an operation will have the necessary material and equipment on hand when needed. Due to the speed at which construction jobs proceed, no single operation continues long enough to become safe through trial and error. To cope with safety problems peculiar to our industry, this procedure has been established so that construction management can predetermine the hazards and develop an appropriate plan to prevent the hazards from becoming accidents.

\subsection{RESPONSIBILITY}

It is the responsibility of the appropriate field supervisory personnel to ensure that Prephase Planning JHA is done for all divisions of work operations and activities performed on this project by each LLNL and non-LLNL employee.

1. Prephase JHAs will be developed by the field supervisory personnel who will be actually running the job(s) or operation(s) that is being preplanned. It is vital that all LLNL and non-LLNL employees and their contractors/subcontractors/subtiers are involved in this JHA process. This analysis will be done on the attached JHA form.

2. The supervisory personnel referenced above shall consult and coordinate the preparation of prephase plans with the Construction Management team to ensure acceptable plans. In addition, the plans will be reviewed and updated at reasonable periods of time to include unanticipated hazards and changes in job conditions. 


\subsection{PREPHASE MEETING}

After the responsible supervisory personnel have completed their necessary preparations and have a prephase JHA written out on the attached form, the CM will call a prephase meeting. This meeting will always be attended by the supervisory personnel of the groups submitting the plan, the CM Safety Coordinator, and any other supervisory personnel responsible for that particular phase of work. Copies of the written plan will be distributed to all those present, and the originator of the plan will be asked to go down his/her list of items explaining each one and allowing comments from all those present. Work will not be allowed to begin without the JHA first being reviewed and accepted.

\subsection{FIVE-MINUTE SAFETY PLANNING MEETING}

A minimum of five minutes shall be used at the start of every shift to discuss the work for the day and the safety planning, precautions, and requirements to be taken to mitigate the risk of an injury. This activity shall be documented. All changes to work activity throughout the day will require the same safety and preplanning commitment.

\subsection{CONSTRUCTION ACTIVITIES}

The list below includes construction activities requiring prephase JHA plans but is not fully inclusive:

Demolition

Excavation and trenching

Earthwork, pile driving, paving

Concrete and masonry work

Structural steel erection including metal decking, miscellaneous steel

Roofing and waterproofing work, including metal roofing and siding

Mechanical work

Scaffolding work

Electrical work

Conveying systems

Hazardous chemicals use

Surveys

Environmental/cultural activities 


\subsection{SAFETY CONCERNS}

Listed below are only some of the safety concerns that should be considered in each of the different construction activities:

1. Layout of haul roads, speed limits, access roads, storage areas, utilities, shop area, offices, fuel storage tanks, parking areas, electrical distribution lines.

2. Temporary electrical installations (methods of supplying electrical power and lighting).

3. Types of equipment to be used.

4. Types of protective equipment used.

5. Methods of cleanup (types of equipment and procedures planned for use).

6. Methods and coordination of handling materials.

7. Concrete construction (type of forming, shoring, erection of precast concrete, lifting, placing, etc.).

8. Access to work areas and work platforms.

9. Methods of minimizing exposure to falls.

10. Trenching and excavation safety

11. Methods of scaffolding.

12. Methods of lighting.

13. Methods of painting (health hazard involved).

14. Connecting and disconnecting utility services (gas, water, electrical, sewers).

15. Health hazards, hazardous chemicals, personal protective equipment.

16. Lockout/tagout of energy sources. 


\subsection{FORM S+H 5-1 JOB HAZARD ANALYSIS}

\begin{tabular}{|c|c|c|}
\hline JOB HAZARD ANAL & & Date: \\
\hline Contract (if applicable): & & Phase: \\
\hline LLNL Group/Contractor & contractor/Subtier: & Location: \\
\hline NIF Element: & & Location: \\
\hline ACTIVITY OPERATIONS & $\begin{array}{l}\text { UNSAFE CONDITION, } \\
\text { ACTION Or OTHER HAZARD }\end{array}$ & $\begin{array}{l}\text { PREVENTATIVE or } \\
\text { CORRECTIVE ACTION } \\
\text { THAT WILL BE TAKEN }\end{array}$ \\
\hline & & \\
\hline & & \\
\hline & & \\
\hline & & \\
\hline & & \\
\hline & & \\
\hline & & \\
\hline & & \\
\hline & & \\
\hline & & \\
\hline & & \\
\hline & & \\
\hline & & \\
\hline & & \\
\hline & & \\
\hline & & \\
\hline & & \\
\hline & & \\
\hline & & \\
\hline & & \\
\hline & & \\
\hline
\end{tabular}

CM Concurrence

LLNL Group/Contractor/Subcontractor Concurrence

Subtier Concurrence 


\section{Hazard Communication and Hazardous Material Guidelines}

\subsection{HAZARD COMMUNICATION}

All LLNL and non-LLNL employees (as defined in Section 1 of this Plan) are covered by a Hazard Communication program as outlined in the LLNL Health $\&$ Safety Manual, Supplement 7.02, "LLNL Health Hazard Communication Program," and NIF CSP, Appendix A, Section 3, "Hazardous Material Control." Contractors and their subcontractors may be required to submit their own Hazard Communication Program when also required to submit a site-specific safety plan.

\subsection{HAZARDOUS MATERIAL AND WASTE MANAGEMENT GUIDELINES}

The handling and control of hazardous materials and waste management guidelines for all LLNL and non-LLNL employees (as defined in Section 1 of this Plan) are outlined in the LLNL Health \& Safety Manual, Chapter 8, "Hazardous Material Control," and NIF CSP, Appendix A, Section 3, "Hazardous Material Control." 


\section{Employee Safety and Health Rules}

\subsection{EMPLOYEE GENERAL SAFETY AND HEALTH RULES}

\subsubsection{GENERAL}

1. PURPOSE

The purpose of this Section is to assist all LLNL and non-LLNL employees, in establishing basic safety and health rules for the Lawrence Livermore Laboratory NIF Conventional Facilities Project. Strict enforcement of and compliance with the NIF CSP and both OSHA and CAL/OSHA Safety and Health Regulations will aid in keeping personnel injuries, occupational illnesses, and equipment and property damage to achieve our ZERO injury/illness goal. All LLNL and non-LLNL employees shall comply with the guidelines established in the LLNL Health \& Safety Manual for areas not covered under the NIF Construction Safety Program. In addition to the safety and health rules presented in this section of the Plan, LLNL and nonLLNL employees shall follow the rules as established in Appendices of the CSP (see attached Appendix A and Appendix B).

2. GENERAL SAFETY AND HEALTH RULES

These rules apply to all LLNL and non-LLNL employees, contractors/subcontractors, visitors and vendors, including employees with supervisory and nonsupervisory assignments. The General Safety and Health Rules shall be used by management to promote accident prevention through indoctrination, safety and health training, and on-the-job application.

All employees must certify on Form S+H A-1 that they have read and understood, or have been briefed and understood, the NIF CSP General Safety Rules and the General Rules - Code of Safe Practices (see Appendix A, Section 1). (An interpreter must brief those employees who do not speak or read English fluently).

3. CRAFT SAFETY AND HEALTH RULES

As a minimum requirement, supervisors and all employees must learn and abide by the General Rules plus the Safety and Health Rules that are applicable to their particular skill or occupation. These rules should be incorporated into pre-work indoctrination.

NOTE: Individual Craft Safety and Health rules apply not only to supervisors and to workers, but also to helpers, assistants, apprentices, and to anyone else who might be in the work area. Supervisors shall ensure that new workers or visitors are made aware of and abide by the safety and 
health rules that are in effect. The underlying general safety and health rules are not all inclusive, and it is our intent to highlight the most common and pertinent.

\subsubsection{GENERAL SAFETY AND HEALTH RULES}

1. ELECTRICAL

A. Batteries. When handling acid or batteries, wear face shields and protective clothing such as rubber gloves and aprons. Immediately flush with water any acid coming into contact with your skin. Avoid breathing acid vapors.

B. Danger Signs and Tags. Be alert to and strictly obey all warning and danger signs around electrical apparatus. Do not close a switch that has a danger tag on it signed by or placed there by someone else.

C. Electrical Hazards. Do not use extension cords or any power tools or equipment when the cords are frayed, worn out, or the wires are bare. Report such hazards to your foreman or turn the equipment in for repair.

D. Grounded. Do not use electric power tools or equipment that is not properly grounded.

E. Qualification. Only qualified electricians are permitted to install, repair, or remove electrical wiring or equipment.

F. Respect Electricity. Electricity must be respected at all times. Remember even a little electric current can be a killer.

G. Temporary Lighting. Report all unguarded or broken light bulbs. Do not hang lights by their cords unless the light was designed to be suspended in that manner.

\section{EQUIPMENT}

A. Contractors will ensure that all mobile equipment such as trucks, cars, cranes, forklifts, etc., be maintained and in good operating condition prior to entry onto the construction site.

i. Equipment and vehicles shall be so constructed as to prevent material being transported from falling off the equipment onto roadways. It shall be the Contractor's responsibility to remove any debris/materials should it fall from their equipment.

ii. Contractors shall be responsible for removing material (mud) tracked onto existing laboratory roadways or walkways, etc. 
iii. When mobile equipment is not in use, it shall be positioned where it will not obstruct roadways, walkways, electrical lines, emergency exits, fire fighting equipment, and temporary ways. All equipment not in use shall be secured or positioned to prevent movement or operations. Mobile cranes shall not be parked with the boom suspended over walkways or other passageways, roadways, railroads, vehicles, electrical or mechanical equipment, or buildings. If loads are left suspended, barricades are to be placed around the area under the load.

iv. When mobile equipment is in use, warning clearances shall be maintained to prevent anyone from accidentally entering the equipment's danger area.

B. Danger Zones. Keep clear of all heavy equipment. Particular points of danger are blind spots to sides and rear of vehicles and in swing radius of cranes and shovels.

C. Elevated Loads. Be alert to avoid swinging or suspended loads. Keep yourself and your fellow workers in the clear at all times.

D. Hoists and Elevators. Ride only on authorized personnel hoists or elevators. Do not ride on a material hoist.

E. Jumping. Do not jump on or off equipment or vehicles, either moving or stationary. When climbing on or off machinery, face the unit and use secure hand and foot holds to prevent slips or falls. Look before you step down.

F. Mechanical Guards. Do not operate machines until all guards are in place. Guards are not to be removed except when necessary to make repairs and are to be replaced before equipment is again put into operation.

G. Operating_Machinery. Only authorized and properly trained, licensed, and supervised personnel are permitted to operate equipment, forklifts, vehicles, valves, electrical switches, and other similar machinery.

H. Seat Belts. If a vehicle or piece of equipment is equipped with seat belts, the operator and the passengers shall use them.

I. Transportation. Ride only in vehicles designated for transporting personnel. Do not ride on running boards, fenders, or other projections and do not extend legs, feet, arms, hands, or other body parts over the edge of the truck bed. 


\section{RIGGING}

A. General. This procedure provides guidance for the protection of personnel engaged in rigging operations.

B. Wire Rope. Reels of wire rope must not be dropped from a car or truck. To keep the wire rope clean and dry during storage, it should be coated with a protective material (LEPRO) to seal out air and moisture. Whether in storage or in use, all wire rope should be kept well lubricated. Wire rope will not be stored where it might be exposed to acid fumes or other corrosive agents.

To avoid kinks, the reel of wire rope must be mounted on jacks or a turntable to allow it to revolve as rope is pulled off. During installation, the rope should be made to turn the same direction off the reel as onto the drum to avoid reverse bends. During the break-in period, the new rope should be run without a load. The first load should be gradually increased to set the wire.

Wire rope will be discarded when found to contain: six randomly distributed broken wires in one rope lay, three broken wires in one strand of one rope lay, or when the rope shows signs of excessive wear, kinks, corrosion, or other defects. Wire ropes with splices will not have less than three tucks. " $U$ " bolt wire rope clips will be applied so that the "U" section is in contact with the "dead end" of the rope.

C. Slings. All slings and their fittings and fastenings shall be inspected prior to use, and as necessary during use, by a competent person for evidence of overloading, excessive wear, or other damage.

Defective slings shall immediately be removed from service and destroyed.

Proper storage shall be provided for slings, etc.

Protection shall be provided between the sling and any sharp, unyielding surfaces.

D. Drums and Sheaves._The size of drums and sheaves will vary according to the size and flexibility of the cable.

The sheaves will be of the proper size so as not to pinch the cable. The grooves of drums and sheaves should be kept smooth and free of burrs or defects. Sheaves, drums, and rollers should be properly aligned. Misalignment causes excessive wear to the cable and, over a period of time, may wear off an entire flange of sheaves. Over-winding and crosswinding should be avoided; either will abrade and distort the rope. 
Check the groove diameter of all sheaves with a "groove gauge." Using wire rope in an oversized sheave causes the rope to become flattened or distorted; using undersized grooves will pinch and tear the strands of wire.

Check the sheaves and blocks for worn bearings. Allowing the sheaves to wobble on the pins will cause the wire rope to rub and wear the sides of the sheaves' throat.

E. Rigging Operations. When temporary rigging such as wire rope lashing, come-alongs, chain-falls, etc., are used for support during all erection sequences for machines, piping, platforms, walkways, and steel members, such rigging shall not be removed until all leveling and alignment is complete, and the item is secured in its permanent location.

Rigging equipment will be inspected before each use, and as necessary during its use, to ensure that it is sound. All rigging equipment including, but not limited to, slings (wire and nylon), chain-falls, comealongs, spreaders, lifting beams, etc., shall be inspected on a quarterly basis. Records will be maintained and copied to the Safety Coordinator. The inspection shall be performed by a competent person, and the rigging equipment color coded in accordance with the Ground Fault Protection suggested color code for the quarter.

Defective rigging equipment will be removed from service immediately and repaired or destroyed.

Rigging equipment, including shackles and hooks, will not be loaded in excess of its manufacturer's recommended safe working load. Special custom designed grabs, hooks, clamps, etc., shall be marked to indicate safe working loads and shall be proof-tested prior to use to 125 percent of their rated loads.

Job or shop hooks formed from bolts, rods, rebar, etc., will not be used. No "Christmas Treeing" shall be allowed on the construction project.

\section{CRANE LIFT}

A. General. This procedure provides guidance for control of lifts with cranes, which are considered to be "critical" lifts and not repetitive lifts. Lifts that fall into this category are those lifts which:

i. Exceed $75 \%$ of the crane's rated capacity for the crane configuration.

ii. Require two cranes to make the lift. 
iii. Are located such that the load or the crane boom could fall onto electric power lines, transformers, pipelines, or vessels or reactors containing flammable, explosive, or hazardous gases or liquids, etc.

iv. Utilize poles and derricks that have been erected for a specific lift.

B. Interpretation. Crane configuration as used in this procedure refers to variable parts of the crane such as boom length, boom angle, counterweight, outrigger's extended and set, tracks extended or retracted, and various attachments (jib, headache ball, load block, lifting devices, etc.). All these items affect the gross capacity of the crane and shall be taken into consideration prior to lift.

C. Guidelines. If, in completing the permit, it is determined the lift equals or exceeds $95 \%$ of the crane configuration capacity for the greatest radius the load will achieve during pick, swing, or set, the lift will not be made. If, by changing the crane configuration within the manufacturing specifications, a greater gross capacity may be gained, the change shall be made. If not, a larger capacity crane shall be ordered and used.

D. Responsibilities. A "Crane Lift" Permit will be completed by the Contractor or organization (e.g., M\&O) prior to making any "critical lift." After the permit has been completed by the supervisor, the required personnel will review and sign off on the lift permit in the order listed on the permit. A copy of the permit will be placed in the cab of the liftcrane, and the original will be filed in the contractor's (or responsible organization's) on-site office.

E. Other Hazards. For any electrical or other hazard(s) involved or associated with the operations, the appropriate hazard permit(s) will also be completed prior to the lift.

F. Operation of Any Crane.

The Supervisor of the crane operator shall:

i. Ensure that operators assigned to a particular piece of equipment are experienced and qualified to use that equipment.

ii. Survey the specific area where the crane will be operating, making certain that all interfering conditions and factors are pointed out to the operator, and that appropriate preventive action is taken prior to the start of operation.

iii. Provide adequate job instruction to the operator.

iv. Specifically instruct the operator that if any portion of the machine does not function properly, the machine is to be stopped, the Supervisor is to be contacted, and further instructions will be delivered. 
v. Instruct the operator that he/she must be able to see the boom tip at all times. Be certain to keep height of rig below the limits established by the FAA.

vi. Ensure proper operating and mechanical condition of the machine.

vii. Exercise extremely good judgment about being present and directly contribute to the handling of extremely heavy or difficult lifts.

viii. Have the swing radius of the counterweight barricaded.

ix. Keep two pairs of orange gloves or vests on the crane to be used by flagpersons to distinguish themselves from other personnel.

The Supervisor of personnel using the crane shall:

i. Survey the specific area in which the crane will be working, making certain that all interfering conditions and factors are noted and that appropriate preventative action is planned and implemented before starting the operation.

ii. Give adequate job instructions to all personnel concerned (especially the crane operator).

iii. Assign a flagperson (or more if required) who is knowledgeable about rigging practices, crane capacity, and operating procedures to provide all signals to the crane operator.

iv. Fully instruct the flagperson regarding the planned use of the crane. (In all cases involving assignment of one flagperson or multiple flagpeople, ensure that each understands his/her responsibilities.)

$v$. Whenever there is any question of whether the weight of a load to be handled or the handling requirements of a particular load might overload the crane, the foreman shall have the weight of the load confirmed (by contacting the vendor directly or by some other means).

A Flagperson must be present at all times whenever:

i. The crane is to be working within a boom's length of an electric power line(s).

ii. The operator cannot clearly see the hook or load at times.

iii. The machine is being backed or moved and the operator cannot see some parts of the machine or its path of travel. 
The flagperson shall:

i. Position himself/herself in full view of the operator and, if using hand signals, be close enough for the signals to be seen clearly. His/her position shall allow a full view of the load and equipment at all times, yet be such that there is no danger of being injured.

ii. Be qualified by experience, knowledgeable in the operation, and able to coordinate actions with the crane operator by signals.

iii. Be responsible for keeping all authorized personnel beyond the crane's operating radius.

iv. Direct the load, ensuring that it never passes over the other personnel.

v. Stay in constant communication with the crane operator by either using approved hand signals, radio, sound-powered phones, or equivalent means of communication.

Cranes/Crawlers-Truck and Wheel Mounted. The Contractor shall ensure and provide certification information as required by OSHA for all cranes prior to site entry. Certification information shall verify that a thorough, annual inspection of the equipment has been made by a professional engineer or agency recognized by the governing body. Equipment owners are required by OSHA to maintain a record of the dates and results of inspections for each hosting machine and piece of equipment.

\section{FIRE PREVENTION AND CONTROL}

A. Cleaning Agents. Do not use explosive liquids as cleaning agents. Use only approved cleaning fluids.

B. Combustible Materials. Store gasoline and similar combustible liquids in secure, approved containers and in an area free from burning hazards.

C. Combustible Materials. Keep all heat sources away from combustible liquids, gases, or other flammable materials. When not in use, store combustible materials in a well ventilated, cool place.

D. Fire Extinguisher. Do not remove or tamper with fire extinguishers installed on equipment or vehicles or in other locations unless authorized to do so or in case of fire.

E. Fire Fighting Equipment. Keep fire fighting equipment free from obstacles, equipment, materials, and debris that could delay emergency 
use of such equipment. Familiarize yourself with the location and use of the project's fire fighting equipment.

F. Oily Rags and Waste. Discard and/or store all oily rags, waste, and similar combustible materials in metal containers on a daily basis.

G. Safety Cans. When handling flammable liquids by hand containers, use approved safety containers with spring-closing covers and flame arrestors.

H. Smoking and Fires. Extinguish all matches, cigarettes, cigars, and pipe tobacco before discarding. Do not smoke while fueling equipment or while in close proximity to refueling areas. Never leave open fires unattended.

I. Storage. Do not store flammable substances on equipment or vehicles unless such unit has an adequate storage area designed for such use.

J. Types of Fires.

i. Class A (wood, paper, trash)-use water or foam extinguishers.

ii. Class B (flammable liquids, gas, oil, paints, grease)-use foam, $\mathrm{CO}$, or dry chemical extinguisher.

iii. Class C (electrical) - use $\mathrm{CO} 2$ or dry chemical extinguisher.

\section{FIRST AID/HEALTH/SANITATION}

A. Accident. Avoid unnecessary moving of an injured person. Notify first aid immediately and keep the injured person as comfortable as possible until first aid personnel arrive.

B. Burns. Immediately treat acid, caustic, and thermal burns by flushing with cold water, then report promptly to first aid.

C. Drinking Cups. Do not drink out of a common dispensing cup or ladle. Use only drinking fountains or individual disposable cups.

D. Drinking Water. Drink water that is specifically supplied and marked for drinking purposes. Stream or river water may look clear and clean but may contain deadly contaminants.

E. Electrical Shock. Turn electric power off, or use a dry board, stick, or other nonconducting object to remove the contact from the victim. Do not touch the victim until he or she is free from current contact.

F. Hygiene. Personal cleanliness is extremely important. Many skin irritations result from careless or incomplete washing or bathing. Wash 
thoroughly and dry the skin completely to eliminate skin rashes, irritations, and infections.

G. Redressing. If it is necessary to have an injury redressed, report to first aid and to your supervisor immediately.

H. Reporting. Report all injuries, no matter how slight, to first aid and to your supervisor immediately.

I. Treatment. Follow all advice given by trained first aid attendants, nurses, or physicians relating to your injury.

\section{GENERAL RULES}

A. Alert. Always be as familiar as possible and alert at all times to conditions and work processes in surrounding areas and with the presence of other workers and equipment so that you can foresee and avoid possible dangers.

B. Barricaded Areas. "Roped off areas" or areas enclosed with barricades are considered danger zones and shall be respected as such. Admittance to or passage through such areas is prohibited without permission except to those employees working within the barricaded area.

C. Barricades. When work requires barricades or floor opening covers to be temporarily removed, keep area secured until the work is finished and then reinstall the barricade or floor covering immediately.

D. Be Sure.

i. You know how to do the job in a correct, safe manner.

ii. You know the hazards and how to protect yourself.

iii. You ask the advice of your supervisor if you are not sure.

E. Firearms and Explosives. Firearms and explosives are prohibited within the NIF project areas or on equipment and other facilities.

F. Molten Metal. In pouring or assisting in pouring molten metal or other hot fluids, use safety glasses, face shields, and adequate body covering. Burn-proof suits with hoods are a suitable substitute. Make sure the pour area is completely dry and free from moisture of any kind. Otherwise dangerous splattering and explosion can result.

G. Moving Cables. Do not touch or guide moving cables or running wires with any part of your body. Keep your hands and fingers away from blocks and sheaves. Stand clear of all cables, wires, and lines that are under strain. 
H. Safety Meetings. Attend and take an active part in all Safety Training Meetings and actively support the company's safety program as a part of your job. Read and abide by all safety materials made available to you. They concern your safety and health and the safety and health of your fellow workers.

I. Speed. Do not try to place speed above safety. An efficient, safe worker is better than a speedy, careless one.

J. Throwing. Do no throw or drop materials from one area or level to another unless every precaution is taken to eliminate the possibility of damaging equipment or injuring persons.

K. Unsafe or Unhealthy Practices and Conditions. Report all unsafe or unhealthy practices and conditions to your supervisor at once.

L. Warning Signs. Be alert for and heed all warning signs at all times.

M. Watch Out. Be watchful of everyone else, as well as yourself, so there will be fewer accidents, and the job will be a much safer place to work.

\section{HOUSEKEEPING}

A. Clean-Up. Keep your work area clean and safe at all times. Always keep yourself, the equipment you operate or are using, and your place of work as clean as practicable. All contractors are responsible for clean "broomswept" areas. Dust control is the responsibility of all contractors.

B. Employee Facilities. Cooperate in keeping change rooms, toilets, first aid, and drinking facilities in clean, sanitary condition.

C. Good Housekeeping. Good housekeeping will reduce confusion on the project and will result in a safer, more efficient operation.

D. Nails and Exposed Rebar. Immediately remove, bend over, or cap protruding nails, rebar, screws or other metal in form lumber, boards, etc., to prevent puncture injuries.

E. Oily Rags and Wastes. Keep oily rags, waste, or other combustible debris in a metal container provided for that purpose.

F. Removal of Debris/Garbage. When cleaning up, do not throw or drop materials from elevated levels to lower levels unless the area below is properly barricaded and adequate warnings are posted.

G. Slipping Hazards. Clean up or eliminate slipping hazards such as grease, oil, water, ice, snow, or other liquids on walkways, ladders, stairways, scaffolds, or other access ways or working areas. 
H. Trash and Debris. Deposit trash, refuse, debris, lunch papers, and other waste in the proper refuse containers.

I. Tripping Hazards. Help keep the work area, especially roadways, access ways, aisles, stairways, scaffolds, and ladders clear of obstructions that may cause tripping or other accident hazards.

\section{LADDERS}

A. Ascending and Descending. Face the ladder and use both hands when going up and down. Materials and tools should be lowered or raised by a rope or other mechanical means.

B. Good Condition. Select the right ladder for the job. Do not use a ladder with missing or defective rungs, split side rails, or other weaknesses.

C. Painting. Do not paint wood ladders as this may cover up defects.

D. Placing and Securing.

i. Place a ladder so that it extends at least 3 feet beyond the top landing. Make sure the base of the ladder is tied off or otherwise secured to prevent slipping or falling.

ii. Set the base of a ladder out at least one-fourth of the ladder height measured from bottom to point of bearing.

E. Work Safely. When working from a ladder, do not overreach or work beyond the second rung from the top.

\section{MATERIAL HANDLING AND STORAGE}

A. Access. When storing materials, remember to leave adequate access through walkways. Do not block aisles or exits.

B. Flammable/Toxic. Store flammable and toxic or other harmful materials in properly designated, well-ventilated areas. Observe and abide by "No Smoking" and other warning signs.

C. Heavy Loads. Do not attempt to lift heavy loads without assistance. Learn how to lift properly by bending your knees and keeping your feet together. Avoid strain by lifting with your legs and arms, not your back.

D. Life Lines. When working on material stored in silos, hoppers, tanks or similar storage areas, wear a full body harness attached to a life line and have somebody standing by in case of an emergency.

E. Noncompatible Materials. Avoid stacking noncompatible materials in the same pile. 


\section{SCAFFOLDING}

Contractors are responsible for evaluating all scaffolding operations. The scaffolding crew shall work under the direction of a trained, certified, and competent scaffolding supervisor. Some general safety rules include:

A. Avoid Overloading. Do not overload a scaffold. Make sure it will hold the load it is to bear.

B. Guardrails. Do not work on scaffolds without adequate guard rails and toe boards.

C. Inspection. Inspect the scaffold before you use it to be sure it is safe and without defects. Do not work on slippery scaffolding until it is cleared or sanded.

D. Makeshift Scaffolds. Do not use makeshift scaffolds. Scaffolds shall be constructed in a safe manner using approved scaffold planking or other material. Make certain the scaffold is placed on a firm footing.

E. Rolling Scaffolds. Dismount scaffold when it is to be moved. Be sure to lock the wheels before remounting. Also remove or secure tools and materials before moving scaffold.

\section{TOOLS}

A. Damaged or Defective Tools. Do not use broken, defective, burned or mushroomed tools. Report defective tools to your supervisor and turn tool in for replacement.

B. Hard Facing. Do not strike two hardened steel surfaces together, i.e., two hammers or a hammer and hardened steel shafts bearings, etc.

C. Power Tools. Only assigned, qualified operators will operate power, explosive-actuated, or air-driven tools.

D. Proper Tool. Always use the proper tool and equipment for any task you may be assigned to do. For example: do not use a wrench as a hammer or a screwdriver as a chisel.

E. Storage. Keep tools in their proper storage place when not in use. Do not leave tools where they might present a tripping hazard, fall on somebody, or be stolen. Do not carry sharp-edged tools in your pockets.

F. Tether tools that are exposed to a possible fall from one level to another to prevent injury to personnel or damage to equipment. 


\subsection{PERSONAL PROTECTIVE EQUIPMENT}

\subsubsection{PURPOSE AND OBJECTIVES}

The purpose of personal protective equipment is to reduce the potential for injuries or detrimental affects on health, which are not controllable by engineering or administrative means, to all LLNL and non-LLNL employees. The use of personal protective equipment for protection from identified hazards is mandatory under the following conditions:

1. Where required by law.

2. Where exposure to the hazard has the potential for injury or illness to an employee.

3. Where there is a potential for damage or contamination to property or the environment.

4. Where the failure to utilize the equipment would expose nonemployees to a safety or health hazard.

\subsubsection{SCOPE}

The requirements set forth herein pertaining to personal protective equipment shall apply at all locations, whether permanent or temporary. It is the employer's responsibility to provide personal protective equipment and to ensure its proper use wherever necessary.

\subsubsection{NIF CONSTRUCTION SAFETY PROGRAM POLICY.}

1. All employees shall use the protective equipment prescribed by the regulatory authorities, such as DOE, Federal-OSHA, and contractors rules and regulations to control or eliminate any hazard or other exposure to illness or injury. Any employee who willfully refuses to use the prescribed protective equipment designed to protect him or her or willfully damages such equipment shall be subject to disciplinary action that may lead to his or her immediate termination.

2. Ear Plugs or Muffs. The use of hearing protection is mandatory where workplace daily noise levels exist with the possibility that employees receive exposure in excess of the allowable noise. The hearing protection devices chosen for use must conform to all applicable federal, state, and local safety and health regulations. Noise levels for exposures to LLNL and non-LLNL employees will be evaluated by ES\&H Team 2. Contact Team 2 when in doubt for an assessment.

3. Eye Wear, Goggles, Safety Glasses, Face Shield, and Helmets. This could include, but not be limited to, grinding, chipping, sanding, sandblasting, or 
use of chemicals. Safety glasses or face shields must conform to the ANSI Standard for Occupational and Educational Eye and Face Protection, Z87.1.

4. Eye protection shall be worn at all times within the NIF site and layout area. Approved welding helmets and appropriate protective eye wear is required on-site by all employees during machinery activities that require appropriate protection.

5. Hard hats are required in all construction areas. The head protection devices shall meet the specifications contained in the ANSI Z89.1, Requirements for Industrial Head Protection.

Hard hats for the protection of employees exposed to high-voltage electrical shock and burns shall meet the specification contained in ANSI Z89.2. All employees and visitors must wear company-approved hard hats during work hours while inside construction areas.

6. Respirators. When it is determined that effective engineering control of oxygen deficiency or air contaminant exposure is not feasible, appropriate respiratory protection will be provided for use by the exposed employees. Use will be mandatory whenever a potential respiratory hazard exists. The selection, use, and maintenance of respirators shall comply with all applicable state/federal, ANSI Z88.2, and local laws pertaining to safety and health. Approved respirators (Mine Safety and Health Administration) will be used when excessive dusts, mists, fumes, gases, or other atmospheric impurities are determined to be harmful to health. Contractors are responsible to provide a written respiratory protection program to Construction Management if respirators are on site. For LLNL and nonLLNL employees, a Hazards Assessment must be written by Hazards Control Industrial Hygiene, which will specify requirements for respirators issued by LLNL. Contact ES\&H Team 2 for assistance. Medical approvals for respirator use will be conducted in accordance with the LLNL Health $\mathcal{E}$ Safety Manual, Chapter 5, Medical Program.

7. Harnesses and Lifelines. Full-body safety harnesses will be used by all employees working from unguarded surfaces where falls to a different level GREATER THAN SIX (6) FEET presents a hazard. Each employee will also wear a safety harness with a safety lanyard secured to a separate lifeline while working from swing scaffolds, boatswain chairs, or other suspended work platforms where a falling hazard is present. Employees shall comply with OSHA's fall protection requirement. Safety Belts will not be allowed, only the use of a full-body harness and shock-absorbing lanyard, or chainpositioning lanyard will be acceptable. The project will be a $100 \%$ tie-off project, requiring the use of two lanyards when exposed to a fall greater than six(6) feet. Employees shall comply with all Federal-OSHA, LLNL, DOE, and the NIF Construction Safety Program fall protection requirements. Safety nets shall be provided when work places are more than 25 feet above the ground or other surfaces where the use of ladders, 
scaffolds, catch platforms, temporary floors, safety lines, or other fall prevention measures is impossible.

8. Footwear. All employees working in construction areas should wear stout working boots. In areas where there is danger of falling objects, hard-toe safety boots or shoes shall be worn.

9. Dress Code. Employees working in construction areas are required to wear clothing for the appropriate season. Shirts shall have a minimum of 4-in. sleeves. Tank tops and sleeveless shirts are not allowed. Pants should be long enough to cover the top of appropriate foot wear. Winter clothing should be sufficient to protect against cold-related injuries, i.e., hypothermia and frostbite.

10. Special Equipment. As heretofore stated, the use of personal protective equipment will be deemed mandatory when the hazard cannot be controlled at the source. This shall apply to the use of special protective equipment such as gloves, aprons, sleeves, shoes, hoods, and boots. When it has been determined through site management, statistical analysis, or compliance requirements that the use of special protective equipment is needed to provide hazard control, this mandatory use requirement shall apply.

11. Visitors. The mandatory use of personal protective equipment will apply to all visitors in areas where use of such equipment is required. 


\section{LLNL - NIF CONVENTIONAL FACILITIES}

\subsection{FORM S+H A-1 - SAFETY RULES TRAINING, ORIENTATION, AND DOCUMENTATION}

I, hereby acknowledge that I have received training and understand the National Ignition Facility General Safety Rules. 


\section{Safety Training Meeting Talks}

\subsection{GUIDELINES FOR SAFETY TRAINING MEETINGS}

A. Each foreman or supervisor is responsible for preparing and conducting Safety Training Meetings for LLNL and non-LLNL NIF field employees on a weekly basis. Special Safety Meetings should be conducted as soon as possible when notified by the Conventional Facilities (CF) Safety Officer of a serious accident, incident, or potential problem on site. Employees will be notified with pertinent information concerning these incidents in which a common hazard exists or information is necessitated.

B. These meetings are an essential element of the NIF Project's Safety and Health Training Program. It is a proven fact that projects that conduct good meetings attain better safety records than those that have poor, or no safety meetings.

C. To assist in the preparation of material and in presenting a safety training meeting, the following guidelines are provided.

\section{PREPARING FOR THE MEETING}

a. Select the topic for the meeting several days in advance so you will have a chance to become familiar with the subject to be discussed. You should be able to present the talk in a convincing manner without reading it.

b. Schedule the meeting at the same time every week, if possible, and hold it right in the work area. These meetings are generally 5 to 15 minutes in length, so seating is not important. However, make sure everyone can easily see and hear you. A good time to hold the meeting is just after the shift begins or immediately following the lunch break.

c. Just prior to the meeting, gather all the material and/or equipment you need. When possible, use actual demonstrations to illustrate your points. For example, if you are talking about fire extinguishers, have one with you to show what it looks like and how it is used. Have a mushroomed tool head or a broken hammer handle to show how they can cause accidents. If necessary, get someone to help you.

d. The entire crew, if possible, should be present before the meeting is started. 


\section{CONDUCTING THE MEETING}

a. Start on time. Attendees may lose interest if unnecessary delays occur.

b. Make the meeting short and to the point. However, if you get a good discussion going, use discretion about cutting it off too soon.

c. Start the meeting by complimenting the men on some recent good work.

d. Give the talk in your own words.

e. Get your people to participate in the meeting. The purpose of these meetings is to get workers to think about safety problems. Encourage them to offer suggestions for improving safety in the work area or your craft.

f. Maintain control. Do not allow the meeting to develop into a wasteful, time-consuming "bull session."

\section{OTHER ITEMS TO COVER IF APPLICABLE}

a. Review any injury or near miss incident any crew member had during the past week or a Special Safety Meeting topic identified by the CF Safety Officer.

Discuss: what the injury was, how it happened, how it could have been prevented, and steps to be taken to prevent reoccurrence.

b. Review safety violations noted during the past week. Discuss: the nature of the violation and the danger involved and offer constructive criticism without naming anyone in particular.

c. Review the work planned for the week ahead. Discuss: hazards to avoid or control, safety equipment to be used, and safe procedures to be followed.

\section{RECORD KEEPING REQUIREMENTS}

1. Have each employee sign the attendance sheet (Safety Meeting Record, Form $\mathrm{S}+\mathrm{H} \mathrm{6-1)}$ at the conclusion of the meeting and have the supervisor conducting the meeting sign it. A copy of the Attendance Sheet must be forwarded to the CF Safety Officer.

2. Make certain the date, the craft types attending, and the meeting location are listed. 
3. Subjects discussed must be covered in detail. "General Safety" is not specific enough.

E. Each foreman or supervisor who is responsible for preparing a Safety Training Meeting should consult with the CF Safety Officer to obtain the latest update to this material or to receive information.

F. Safety meeting topics are available from the CF Safety Officer and also ES\&H Team 2. 


\section{NIF PROJECT}

\subsection{FORM S+H 6-1 SAFETY MEETING RECORD}

LLNL Group/Contractor/Subcontractor

NIF Element

Contract \#

Supervisor

Date

Craft

Crew

Subject(s) (Briefly Describe)

Comments

No. of employees on crew No. in attendance

Attendees

NAME: PRINT

SIGNATURE
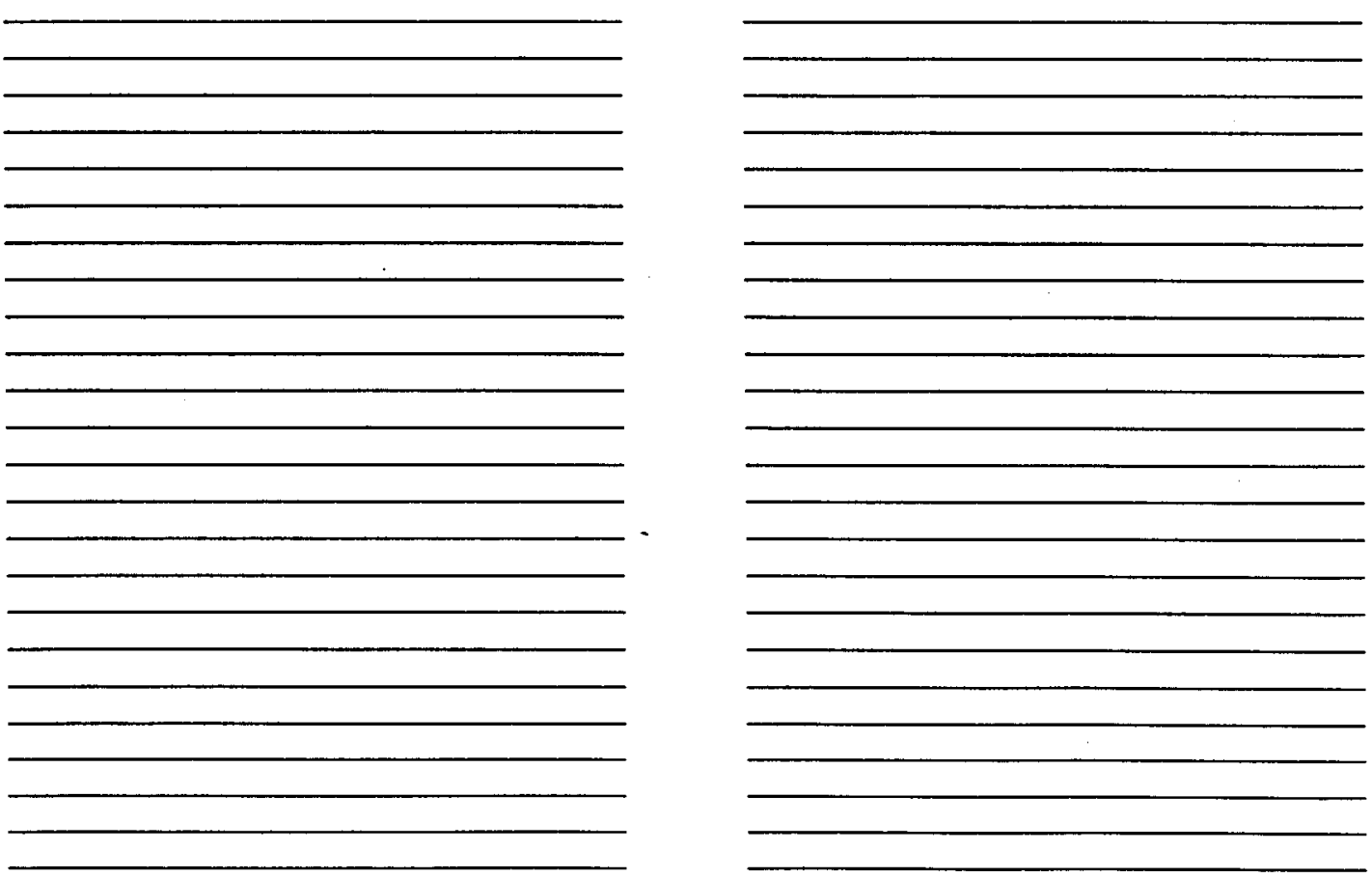